NBER WORKING PAPER SERIES

THE FUTURE OF U.S. CARBON-PRICING POLICY

Robert Stavins

Working Paper 25912

http://www.nber.org/papers/w25912

\author{
NATIONAL BUREAU OF ECONOMIC RESEARCH \\ 1050 Massachusetts Avenue \\ Cambridge, MA 02138 \\ May 2019
}

The author acknowledges valuable comments on a previous version of the manuscript by Lawrence Goulder, Larry Karp, Gilbert Metcalf, William Pizer, Richard Schmalensee, and the organizers of the National Bureau of Economic Research conference on Environmental and Energy Policy and the Economy, as well as comments on my presentation at the conference. The views expressed herein are those of the author and do not necessarily reflect the views of the National Bureau of Economic Research.

NBER working papers are circulated for discussion and comment purposes. They have not been peer-reviewed or been subject to the review by the NBER Board of Directors that accompanies official NBER publications.

(C) 2019 by Robert Stavins. All rights reserved. Short sections of text, not to exceed two paragraphs, may be quoted without explicit permission provided that full credit, including (C) notice, is given to the source. 
The Future of U.S. Carbon-Pricing Policy

Robert Stavins

NBER Working Paper No. 25912

May 2019

JEL No. Q40,Q48,Q54,Q58

\begin{abstract}
There is widespread agreement among economists - and a diverse set of other policy analysts that at least in the long run, an economy-wide carbon pricing system will be an essential element of any national policy that can achieve meaningful reductions of $\mathrm{CO} 2$ emissions cost-effectively in the United States. There is less agreement, however, among economists and others in the policy community regarding the choice of specific carbon-pricing policy instrument, with some supporting carbon taxes and others favoring cap and trade mechanisms. This prompts two important questions. How do the two major approaches to carbon pricing compare on relevant dimensions, including but not limited to efficiency, cost-effectiveness, and distributional equity? And which of the two approaches is more likely to be adopted in the future in the United States? This paper addresses these questions by drawing on both normative and positive theories of policy instrument choice as they apply to U.S. climate change policy, and draws extensively on relevant empirical evidence. The paper concludes with a look at the path ahead, including an assessment of how the two carbon-pricing instruments can be made more politically acceptable.
\end{abstract}

\author{
Robert Stavins \\ JFK School of Government \\ Harvard University \\ 79 JFK Street \\ Cambridge, MA 02138 \\ and NBER \\ robert_stavins@hks.harvard.edu
}




\title{
The Future of U.S. Carbon-Pricing Policy
}

\author{
Robert N. Stavins ${ }^{1}$ \\ John F. Kennedy School of Government, Harvard University \\ Cambridge, Massachusetts 02138
}

In this paper, I seek to compare the two major approaches to carbon-pricing - carbon taxes and cap-and-trade - in the context of a possible future U.S. climate policy, and to do so by treating both instruments in a balanced manner, examining their merits and challenges, without necessarily favoring one or the other. ${ }^{2}$ I try to follow the principle that when making normative comparisons $^{3}$ of policy instruments, it is most valuable to compare either idealized versions of two instruments or realistic (likely to be implemented) versions of both, thereby avoiding a comparison of an idealized version of one instrument with a less-than-ideal, but realistic version of another (Hahn and Stavins 1992).

In the next section, Part I, I describe the key premises I adopt, including the importance of global climate change, the current reality of U.S. inaction at the Federal level, and my view that in the long term a truly meaningful, economy-wide U.S. climate policy will likely need to have carbon-pricing at its core, either in the form of a carbon tax or a cap-and-trade system. Then, in Part II, I examine the normative theory of policy instrument choice as it applies to U.S. climate change policy, with brief reviews of the major options, and particular attention to what normative theory suggests about the choice between price and quantity instruments for abating $\mathrm{CO}_{2}$ emissions. In Part III, I turn to the positive theory of instrument choice as it applies to U.S. climate policy, and assess what positive theory can tell us about this choice of climate policy instruments.

\footnotetext{
${ }^{1}$ Stavins is the A. J. Meyer Professor of Energy and Economic Development at the Harvard Kennedy School, a University Fellow of Resources for the Future, and a Research Associate of the National Bureau of Economic Research. He acknowledges valuable comments on a previous version of the manuscript by Lawrence Goulder, Larry Karp, Gilbert Metcalf, William Pizer, Richard Schmalensee, and the organizers of the National Bureau of Economic Research conference on Environmental and Energy Policy and the Economy, as well as comments on my presentation at the conference. The author, who is responsible for all remaining errors, can be reached at robert_stavins@harvard.edu.

${ }^{2}$ In 2007, I was asked to write a paper for the Brookings Institution's Hamilton Project proposing a national emissions trading system to reduce U.S. carbon dioxide $\left(\mathrm{CO}_{2}\right)$ emissions. I said I would prefer to write about what I considered to be the two symmetric carbon-pricing instruments - a carbon tax and a carbon trading program. But the Hamilton Project leaders said they would find someone else to write about carbon taxes (Metcalf 2007), and I should make the strongest case possible for what is today called cap-and-trade. I did my best, and in the process I came to be identified - and to some degree may have become - an advocate for $\mathrm{CO}_{2}$ cap-and-trade. During the Obama administration transition, the design recommendations in my Hamilton Project paper (Stavins 2007) became the starting point in efforts to structure the administration's proposed $\mathrm{CO}_{2}$ cap-and-trade system that became part of the failed Waxman-Markey legislation, H.R. 2454, the American Clean Energy and Security Act of 2009.

${ }^{3}$ Normative assessment refers to the merits of the instruments, such as in terms of: quantitative emissions reductions, aggregate abatement costs, and distributional impacts. Positive (political economy) prognosis refers to identifying which instrument is more likely to be enacted and implemented.
} 
In Part IV, I examine empirical evidence, that is, what experience can tell us, first with regard to empirical evidence bearing on normative instrument choice, including lessons learned from experience with taxes and cap-and-trade, and then with regard to empirical evidence about positive instrument choices. In Part V, I offer some conclusions from the normative and positive analyses - both theoretical and empirical - and comment on the path ahead.

\section{Setting the Stage: Major Premises}

Gradually, over the twenty-five years since the U.S. Senate ratified the United Nations Framework Convention on Climate Change, scientific assessments of the risk of global climate change have become increasingly compelling (Intergovernmental Panel on Climate Change 2013, 2018), and economic analyses supporting the wisdom of policy action have gained considerable prominence, if not influence (Nordhaus 2015). ${ }^{4}$ While China's annual emissions have surpassed those of the United States since 2006, the U.S. remains the largest contributor to the accumulated atmospheric stock of anthropogenic greenhouse gases (GHGs) (Boden, Marland, and Andres 2017).

Countries around the world - including nearly all of the industrialized countries and large emerging economies - have launched or are in the process of launching national policies aimed at reducing their emissions of GHGs. Of the 169 Parties to the Paris climate agreement that have submitted specific pledges (known as Nationally Determined Contributions or NDCs), more than half (88 to be exact) refer to the use of carbon pricing in their NDCs. To date, some 51 carbonpricing policies have been implemented or are scheduled for implementation worldwide, including 26 carbon taxes and 25 emissions trading systems (Table 1). ${ }^{5}$ Together, these carbonpricing initiatives will cover about 20\% of global GHG emissions (World Bank Group 2018), and many of these systems may eventually be linked with one another under the auspices of Article 6 of the Paris Agreement (United Nations 2015; Bodansky, Hoedl, Metcalf, and Stavins 2015; Mehling, Metcalf, and Stavins 2018).

In the midst of these global and national developments, the current U.S. administration stands out for its rejection of the science of climate change, its decision to withdraw from the Paris Agreement, and its comprehensive moves to reverse climate policy initiatives of the previous administration. In this context, it is of value to assess the long-term future of U.S. climate policy - both normatively and positively.

There is widespread agreement among economists - and a diverse set of other policy analysts - that at least in the long term, economy-wide carbon pricing will be an essential

\footnotetext{
${ }^{4}$ The phrase, "wisdom of policy action," refers to the global dynamic efficiency of cost-effective actions taken to reduce global emissions, without suggesting that the direct climate change benefits to a single country - in particular, the United States - would exceed the costs it incurs through unilateral actions (that is, without being part of effective international cooperation). However, if domestic co-benefits of U.S. climate policies are taken into account, such as the health impacts of reductions in fine particulates due to decreased coal combustion, then a unilateral U.S. climate policy can be welfare improving for the United States (Stavins 2014).

${ }^{5}$ Most of the emissions trading systems are cap-and-trade, but one very important one is a tradable performance standard, namely China's system, officially launched in December 2017 and likely to be implemented in 2020.
} 
element ${ }^{6}$ of any policy that can achieve meaningful reductions of $\mathrm{CO}_{2}$ emissions cost-effectively in the United States, as well as in many other industrialized countries (Metcalf 2009; Kaplow 2010; Borenstein et al. 2018). ${ }^{7}$ The ubiquitous nature of energy generation and use and the diversity of $\mathrm{CO}_{2}$ sources in a modern economy mean that conventional technology and performance standards would be infeasible, and - in any event - excessively costly (Newell and Stavins 2003). The cost advantage of carbon pricing exists because of the flexibility it provides and the incentive it fosters for all sources to control at the same marginal abatement cost, thereby achieving cost-effectiveness in aggregate. In addition, in the long term, pricing approaches can reduce abatement costs further by inducing carbon-friendly technological change (Newell, Jaffe, and Stavins 1999). ${ }^{8}$

There is less agreement among economists regarding the choice of specific carbonpricing policy instruments, with some supporting carbon taxes (Mankiw 2006; Nordhaus 2007) and others cap-and-trade mechanisms (Ellerman, Joskow, and Harrison 2003; Keohane 2009). That prompts two questions. How do the two major approaches to carbon pricing compare on relevant dimensions, including but not limited to efficiency, cost-effectiveness, and distributional equity? And which of the two approaches is more likely to be adopted in the future in the United States? Much has been written by academic economists about the first question; and the second question has been addressed from a number of disciplinary perspectives by social scientists, as well as by commentators in the broader policy community.

Among many findings from this survey and synthesis, two major conclusions stand out. One is that the specific designs of carbon taxes and cap-and-trade systems may be more consequential than the choice between the two instruments. The two approaches to carbon pricing are perfectly or nearly equivalent in regard to some issues and attributes, while significantly different in regard to some others. But many of these differences fade with specific implementations, as elements of design foster greater symmetry. Indeed, what appears at first to be the dichotomous choice between two distinct policy instruments often turns out to be a choice of design elements along a policy continuum. A second major conclusion is that issues of positive political economy - such as the probability that a particular instrument will actually be

\footnotetext{
${ }^{6}$ Carbon pricing may be necessary but it would not be sufficient, because other market failures limit the impacts of price signals (Jaffe, Newell, and Stavins 2005). One example is the well-known principal-agent problem that constrains incentives for energy-efficiency investments by either landlords or tenants in renter-occupied properties. Another is the public-good nature of research and development, whereby firms capture only a share of the benefits of the information their research produces. Both argue for specific policies that would complement a carbon-pricing regime (Stavins 2010).

${ }^{7}$ There is a prominent minority view that carbon pricing is little more than a sideshow, due to the fact that sufficiently high carbon prices are politically unattainable, and that the only politically feasible path is making carbon-free energy cheaper (not making carbon-intensive energy more costly). The thinking from private industry representatives in the renewables sector tends to be that government subsidies are the answer, while the response from some policy analysts is that government-funded research initiatives should be the prime focus (Stepp and Trembath 2013; Sachs 2018). Others recognize that carbon-pricing may be the first-best policy for the long term, but argue that the best set of approaches for the short term may be those that are politically achievable (Gillis 2018; Goulder 2019b). For a comparison of U.S. carbon-pricing (carbon taxes and cap-and-trade) with use of a national clean energy standard and a gasoline tax increase, see Goulder and Hafstead 2018.

${ }^{8}$ Two additional advantages of carbon-pricing instruments are that they encourage demand-side conservation, and can raise revenues for governments, which through judicious use of those revenues, can lower social costs of the policies (Goulder and Hafstead 2018; Metcalf 2019).
} 
adopted and implemented - frequently have normative dimensions, as well. Likewise, normative attributes - ranging from cost-effectiveness to distributional equity - have important implications for any political prognosis.

\section{Normative Theory of Policy Instrument Choice}

For much of the past 100 years, economists have considered environmental pollution to be a classic - indeed, textbook - example of a negative externality, an unintentional consequence of production or consumption that reduces another agent's profits or utility (Pigou 1920). A separate but related strand of literature - stemming from Ronald Coase's work (1960) - has identified environmental pollution essentially as a public-good problem, that is, a problem of incomplete property rights. These two perspectives can lead to different policy prescriptions for climate change: carbon taxes versus tradable carbon rights. ${ }^{9}$

For some 40 years prior to Coase (1960), the literature focused on a single economic response to the problem of externalities - taxing the externality in question. In principle, a regulator could ensure that emitters would internalize the damages they caused by charging a tax on each unit of pollution equal to the marginal social damages at the efficient level of pollution control (Pigou 1920). Such a system makes it worthwhile for firms to reduce emissions to the point where their marginal abatement costs are equal to the common tax rate. Hence, marginal abatement costs will be equated across sources, satisfying the necessary condition for costeffectiveness. In theory, this will hold both in the short term, and in the long term by providing incentives for diffusion (Jaffe and Stavins 1995) and innovation (Newell, Jaffe, and Stavins 1999) of low-cost abatement technologies.

Following Coase (1960), it became possible to think about solving the problem of pollution as one of clarifying poorly defined property rights. If resources such as clean air and water could be recognized as a form of property, whose corresponding rights could be traded in a market, private actors could allocate the use of this property in a cost-effective way. Some fifty years ago, Thomas D. Crocker (1966) and J. H. Dales (1968) each proposed a system of transferable discharge permits that could provide such a market solution: the regulator need only designate the total quantity of emissions allowed (the cap), distribute rights corresponding to this total, and allow individual sources of emissions to trade the permits until an optimal allocation had been reached. This was the fundamental thinking behind what was has come to be known as "cap and trade." 10

Under this approach, an allowable overall level of pollution is established by the government (not necessarily at the efficient level), and allocated among firms in the form of tradable allowances. Firms that keep their emissions below their allotted level may sell their surplus allowances to other firms or use them to offset excess emissions in other parts of their operations. Under these conditions, it is in the interest of each source to carry out abatement up

\footnotetext{
${ }^{9}$ Both the Pigouvian (externality) and Coasian (property rights) approaches are examples of missing markets (Arrow 1969).

${ }^{10}$ Cap-and-trade systems should not be confused with "emission-reduction-credit" or "offset" systems, whereby permits are assigned when a source reduces emissions below some baseline, which may or may not be readily observable (Stavins 2003).
} 
to the point where its marginal control costs are equal to the market-determined price of tradable allowances. Hence, the environmental constraint is satisfied, and marginal abatement costs are equated across sources, satisfying the condition for cost-effectiveness. ${ }^{11}$

Although the two instruments - carbon taxes and carbon cap-and-trade - may be said to derive respectively from the externality (Pigou 1920) and property-rights (Coase 1920) perspectives, the two approaches are more similar than different. A carbon tax would directly place a price on carbon (most likely upstream, where fossil fuels - coal, petroleum, and natural gas - enter the economy), with quantities of carbon use and $\mathrm{CO}_{2}$ emissions adjusting in response. An upstream carbon cap-and-trade system would constrain the quantity of carbon entering the economy through allowances on the carbon content of the three fossil fuels, with prices emerging indirectly from the market for allowances.

In some cases, what may at first appear to be key differences between the two instruments fade on closer inspection, while other apparent differences survive such inspection. I first explore symmetries between carbon taxes and cap-and-trade, and then I turn to significant differences.

\subsection{Equivalence, Similarities, and Symmetries}

To a significant degree, a carbon tax and a commensurate cap-and-trade system are functionally similar, with differences in specific design elements dominating fundamental differences between the instruments themselves (Stavins 1997; Goulder and Schein 2013). I examine six areas of symmetry: (1) emissions reductions; (2) abatement costs; (3) possibilities for raising revenue; (4) costs to regulated firms (with respective revenue-raising instruments); (5) distributional impacts; and (6) competitiveness effects. The findings which emerge in regards to these six areas are summarized in Table 2, where I characterize the symmetries between carbon taxes and cap-and-trade as being perfectly equivalent, nearly equivalent, or similar.

\subsubsection{Emission Reductions}

In the absence of uncertainty, by setting the respective time-paths of the tax rate or the emissions cap, commensurate tax and trading instruments can achieve the same emissions reductions. Both instruments can employ an upstream, midstream, or downstream point of regulation (distinct from the point of allocation of allowances). This does not affect aggregate cost in either case, but it can affect decisions about the scope of coverage, and therefore can affect environmental effectiveness, as well as cost-effectiveness. With either carbon tax or capand-trade, focusing on the carbon content of fossil fuels upstream could enable a policy to capture up to $98 \%$ of U.S. $\mathrm{CO}_{2}$ emissions with a relatively small number of compliance entities on the order of a few thousand - as opposed to the hundreds of millions of smokestacks, tailpipes, and other sources that emit $\mathrm{CO}_{2}$ after fossil fuel combustion (Metcalf 2007; Stavins 2007).

\footnotetext{
${ }^{11}$ In theory, as I discuss later, a number of factors can adversely affect the performance of a cap-and-trade system, including: concentration in the permit market (Hahn 1984); concentration in the related product market (Malueg 1990); transaction costs (Stavins 1995); non-profit maximizing behavior, such as sales or staff maximization (Tschirhart 1984); the preexisting regulatory environment (Bohi and Burtraw 1992); and the degree of monitoring and enforcement (Montero 2007). Some of these also affect the performance of pollution taxes.
} 


\subsubsection{Abatement Costs}

If firms subject to a policy are operating in a competitive market, they have strong incentives with either instrument to minimize their total costs, which include the sum of abatement costs and tax liability, or the sum of abatement costs and cost of allowance purchases (or net of allowance sales revenue). ${ }^{12}$ In both cases, there is an incentive to abate emissions up to the point where each source's marginal abatement cost is equal to the tax rate or the marketdetermined allowance price. Hence, all firms control at the same marginal cost, and so the same (minimized) aggregate cost is experienced across the scope of the policy.

Considering the temporal dimension of the respective policies, an important question is the relative effect of the two approaches on technological innovation. Here, a series of theoretical explorations have found that a tax and a cap-and-trade system (with auctioned allowances $^{13}$ ) are equivalent in their incentives for carbon-saving innovation (Milliman and Prince1989; Jung, Krutilla, and Boyd 1996), or at least that neither system dominates (Fischer, Parry, and Pizer 2003). ${ }^{14}$

Finally, in principle, offsets for emissions reductions outside of the respective programs can be used with either tax or trading regimes, bringing about additional abatement cost savings (Goulder and Schein 2013).

\subsubsection{Possibilities for Raising Revenue}

An important attribute of a carbon tax is that it raises revenue for the government, which can be used for a variety of beneficial public purposes, including but not limited to using the revenue to enable cuts in the rates of distortionary taxes, thereby lowering the net social cost of the overall policy (Bovenberg and Goulder 1996). More broadly, given the need for government revenues for other purposes as well, this is indeed an important attribute of taxes.

Of course, an auction mechanism in a cap-and-trade system can, in principle, accomplish the same outcome (Goulder and Schein 2013). In this regard, of various cap-and-trade designs, it has been estimated that auctioning and recycling revenue via income tax cuts would be the least costly, while the most costly would be recycling revenue through lump-sum dividends or freelyallocated allowances (Parry and Williams 2010). The results are similar for the use of revenue from a tax.

\footnotetext{
${ }^{12}$ Whether firms receive allowances for free (sometimes called grandfathering) in a cap-and-trade system or via auction, they face the same marginal opportunity cost for emissions.

13 Throughout this paper, I frequently include the caveat of considering cap-and-trade systems that include auctioning of allowances, because it is with this design that the symmetry of these price and quantity instruments is greatest.

${ }^{14}$ A related temporal issue is that carbon prices - and, for that matter, performance standards - that devalue existing carbon-intensive capital can have the effect of fostering stranded assets (Rozenberg et al. 2019), which could create political resistance to policies. This can be avoided with policies that target only new investments, as opposed to the existing capital stock, but this would introduce the problems created by vintage-differentiated regulation (Stavins 2006).
} 
Since the systems are theoretically equivalent in their abilities to raise revenue, any differences in this regard would be in terms of implementation. One possible difference is that given the committee jurisdictions in the U.S. Congress, it could be more difficult to link revenuerecycling with a cap-and-trade system than it would be to link revenue-recycling with a carbon tax (Metcalf 2007). This is because in the cap-and-trade case, committees with environmental jurisdiction and those with financial jurisdiction would need to be involved in the legislative process, whereas for a revenue-neutral carbon tax only the financial committees would be necessary. Whether or not this causal chain is the real explanation, there is empirical support for the overall point from global experience, where about $70 \%$ of cap-and-trade auction revenue has been earmarked for green spending, while $72 \%$ of carbon tax revenue has been recycled or dedicated to general funds (Carl and Fedor 2016).

\subsubsection{Costs to Regulated Firms (with Revenue-Raising Instruments)}

The cost of a carbon tax or cap-and-trade system that includes auctioning greatly depends on the use of the revenue. Compared with a lump-sum redistribution of revenue (rebates), recycling through rate cuts in payroll taxes, individual income taxes, or corporate income taxes may have net costs (after accounting for the benefits of eliminating the excess burden of distortionary taxes) that are 15\%, 26\%, and 67\% lower (Goulder and Hafstead 2018). ${ }^{15}$

The results with a cap-and-trade system with complete auctioning of allowances are similar. With a lump-sum rebate, the cost is identical to the rebate paired with a carbon tax. According to one set of estimates, if auction revenue is recycled via cuts in tax rates, then there are "slight differences" in costs, compared with respective cuts in the same tax rates (above) with a carbon tax (Goulder and Hafstead 2018). If allowances are not auctioned, but given out for free, then the costs are considerably greater than with auctioning: at best, $8 \%$ higher than if lump-sum rebates are employed, and 200\% higher than if revenue was recycled through corporate tax rate cuts (Goulder and Haftstead 2018).

If the comparison is between a cap-and-trade system with freely allocated allowances and an ordinary carbon tax, then the cost differential is significant. In fact, free allocation could increase regulatory costs of carbon cap-and-trade enough that the sign of the efficiency impact could conceivably be reversed from positive to negative net benefits (Parry, Williams, and Goulder 1999). On the other hand, as I discuss below, free allocation of allowances would meet with much less political resistance.

It might appear that cap-and-trade systems offer greater opportunities to protect the profits of regulated firms (through free allocation of allowances), but, as I discuss below, the same can be accomplished under a tax regime through inframarginal tax exemptions for emissions below a specified level.

\footnotetext{
${ }^{15}$ All of the numerical estimates in this paper are from analyses carried out prior to implementation of the "Tax Cuts and Jobs Act" of 2017. One effect of that set of tax reforms would be to lessen the magnitude of the efficiency gains that could be achieved from further cuts in corporate tax rates (Metcalf 2019).
} 


\subsubsection{Distributional Impacts}

In principle, either instrument can be designed to be roughly equivalent to the other in distributional terms. If allowances are auctioned, a cap-and-trade system looks much like a carbon tax from the perspective of regulated firms. Likewise, if a carbon tax system includes tradable tax exemptions ${ }^{16}$ for a specified quantity of emissions (that is, the tax is levied only on emissions above a specified amount), then a carbon tax can resemble a cap-and-trade system with freely allocated allowances (Goulder and Schein 2013). This is because inframarginal tax exemptions have the same effect as freely allocated allowances in a cap-and-trade system: they allow a specified quantity of emissions for which a compliance entity need not pay.

Goulder and Haftstead (2018) and others have examined minimum free allocations that could make firms whole in terms of fully compensating them for their compliance costs. In general, these turn out to be a relatively small shares of allowances, yet produce significant decreases in overall costs (with auctioning and recycling of the remainder of allowances). In theory, a similar approach is conceivable with a carbon tax system, namely tradable exemptions to the carbon tax for emissions up to some threshold where the tax begins (Goulder and Hafstead 2018).

Household distributional impacts also can be identical, depending upon two elements of design - the extent of free emissions, and the use of revenue. This emerges from an assessment of two components of household impacts of a carbon price. One of these has been termed "useside impacts," reflecting how a policy affects relative prices of goods and services purchased by households, in other words, impacts that take place through household expenditures. The other has been termed "source-side impacts" reflecting how the policy affects nominal wages, capital, and transfers, in other words, impacts that take place through household income (Goulder and Hafstead 2018; Goulder, Hafstead, Kim, and Long 2018; Metcalf 2018, 2019). On the use side, carbon pricing is generally regressive (ignoring the return of tax revenue), due to changes in the prices of goods and services. Although the degree of regressivity can be altered by the use of the revenue, this effects remains regressive (Goulder \& Hafstead 2018). ${ }^{17}$

However, on the source side, changes in wage and capital income (as well as government transfers) are generally progressive. ${ }^{18}$ Lump-sum recycling of the revenue makes this very progressive. Using the revenue instead for cuts in corporate tax rates, the effect is still progressive, although somewhat less so. Most importantly, in most cases (in the models employed by Goulder and Hafstead 2018, and others), the overall (use-side plus source-side) impact tends to be progressive. Because source-side impacts dominate use-side impacts for most cases where there is revenue recycling (tax rate cuts in payroll or individual income taxes), the

\footnotetext{
${ }^{16}$ A compliance entity which receives more exemptions than needed may sell the exemptions to other entities.

${ }^{17}$ This discussion abstracts from the fact that there can be a mix of winners and losers in any group, which is missed by focusing on averages.

${ }^{18}$ This reflects the fact that carbon-intensive industries (which, of course, face the greatest burden from a carbon tax) tend to be relatively capital-intensive. As a result, the burden of a carbon tax falls more on capital than on labor, and hence tends to reduce returns to capital more than returns to labor. Since capital income represents a larger share of total income for wealthier households than for poorer households, the impacts from reduced returns to capital is progressive.
} 
overall impact of carbon taxes - or cap-and-trade with $100 \%$ auctioning of allowances and the same recycling through tax rate cuts - is progressive. Using the tax or auction revenue for lumpsum rebates is even more progressive. Hence, there is a tradeoff, namely that by using approaches that are more cost-effective (tax rate cuts), the progressivity is less than it is with lump-sum rebates (most progressive, but most costly because distortionary taxes are unaffected).

\subsubsection{Competitiveness Effects}

A frequently expressed concern about new proposals for carbon-pricing policies is their impact on competitiveness. The concern is that by increasing the costs of producing carbonintensive goods and services within a jurisdiction, there will be a shift in comparative advantage to the production of those same goods and services in other jurisdictions that do not face commensurate climate policy compliance costs. In theory, this can produce "leakage" of economic activity and of related emissions.

In reality, such leakage may be relatively modest, particularly if the emissions occur in non-traded sectors, such as electricity generation, transportation, and residential buildings, but energy-intensive manufacturing industries could face incentives to relocate (Aldy and Pizer 2011). Additional emissions leakage may occur through international energy markets, as countries with climate policies reduce their consumption of fossil fuels and drive down fuel prices, those countries without such policies may increase their fuel consumption in response to the lower prices (Aldy and Stavins 2012).

These impacts on competitiveness would be anticipated equally with either type of carbon-pricing policy instrument (and with virtually any meaningful $\mathrm{CO}_{2}$-limiting policy, for that matter). The impacts on energy-intensive manufacturing can be mitigated - in theory - through specific elements of policy design with either instrument. With a carbon tax, border adjustments - a tax on imports of products from countries without commensurate climate policies - can be employed. With a cap-and-trade system, an allowance requirement can be employed for those same imports, together with an output-based updating allocation of allowances (Goulder and Schein 2013), although leakage though international energy markets may remain.

\subsection{Differences and Distinctions}

In theory, there are also some significant differences and distinctions between the two main approaches to carbon pricing. I examine eight such areas: (1) performance in the presence of uncertainty about benefits and costs; (2) price volatility; (3) interactions with complementary policies; (4) potential market manipulation; (5) transaction costs; (6) ease of linkage with policies in other jurisdictions; (7) complexity and administration; and (8) political resistance to simplest forms of both instruments. ${ }^{19}$ The findings that emerge in regards to these eight areas are summarized in Table 2, where I characterize the comparison between carbon taxes and cap-andtrade as representing significant differences, differences, or some distinctions.

\footnotetext{
${ }^{19}$ An additional difference, noted by Goulder and Schein (2013), is the potential for wealth transfers to oil exporting nations (that have market power) if those countries choose to behave strategically in response to the imposition of a cap-and-trade system in the United States, with the result that policy-generated rents can be transferred in part from the domestic economy to the oil-exporting countries. In theory, the same phenomenon would not arise in response to the imposition of a U.S. carbon tax.
} 


\subsubsection{Uncertainty about Benefits and Costs}

Significant uncertainty characterizes the benefits and the costs of environmental protection. For two decades following Weitzman's (1974) classic paper on "Prices vs. Quantities,” it was generally acknowledged that benefit uncertainty on its own has no effect on the identity of the efficient policy instrument, but that cost uncertainty could have significant effects, depending upon the relative slopes of the marginal benefit (damage) and marginal cost functions. ${ }^{20}$ In particular, in the presence of cost uncertainty when (the absolute value of) the marginal cost function exceeds that of the marginal benefit function, then - in expected value terms - a price instrument, such as a tax, is likely to be more efficient (smaller deadweight loss due to mistaken predictions of future costs) than a quantity instrument, such as a cap-and-trade system. When the opposite is the case - slope of the marginal benefit function exceeds slope of the marginal cost function - then a cap-and-trade instrument would be more efficient. ${ }^{21}$

In the Weitzman (1974) analysis, benefit uncertainty has no effect on the relative efficiency of the two instruments. However, twenty years after Weitzman's work, it was noted that when there is simultaneous and correlated uncertainty about marginal benefits and marginal costs, and marginal benefits are positively correlated with marginal costs, then it is more likely than it is solely on the basis of the usual relative slopes analysis to favor the relative efficiency of the quantity instrument (Stavins 1996). The opposite result holds if there is negative correlation between benefit and cost uncertainty. ${ }^{22}$

It was to be another two decades (Karp and Traeger 2018) before any use was made in the climate policy context of the findings from Stavins (1996), which drew on an important insight in Weitzman's original analysis. Much sooner than that, however, Newell and Pizer (2003) and others (Hoel and Karp 2002) applied the Weitzman analysis to the circumstances of climate change. Newell and Pizer reasoned that because greenhouse gases accumulate in the

\footnotetext{
${ }^{20}$ Weitzman's (1974) model assumed uncertainty regarding the level (intercept), but not the slope of the marginal abatement cost function, and assumed no correlation between benefit uncertainty and cost uncertainty. Also, the original analysis considered a situation where the regulator makes a one-time choice of instrument. Subsequent work (as discussed below), relaxed these assumptions.

${ }^{21}$ Intuition for this result is that a steep marginal benefit function suggests large gains or losses in the benefits of abatement with relatively small changes in abatement levels. A tax fixes the emissions price, but allows the quantity of emissions to vary, whereas a quantity instrument fixes the emissions (abatement) level and allows the price to vary. Hence, the quantity instrument is favored when the marginal benefit function is steeper than the marginal cost function. On the other hand, a steep marginal cost function suggests that large increases in the costs of abatement take place with relatively small changes in abatement levels. Hence, a price instrument is favored.

${ }^{22}$ Intuition for this result is that if emission taxes are used to control pollutant emissions, firms will respond to unexpectedly high marginal control costs by reducing their control efforts. But if there is a positive correlation between uncertain benefits and uncertain costs, then at the same time that firms are reducing their control efforts, the marginal benefits of those efforts will be unexpectedly great. Hence, the firms' natural response to the emission tax will be less appropriate than indicated by the simple relative slopes rule. On the other hand, if there is a negative correlation between the marginal benefits and marginal costs of control, then unexpectedly high marginal control costs will be associated with unexpectedly low marginal benefits, meaning that a tax instrument will lead firms to reduce their control efforts (because of high control costs) at times at which the marginal benefits of those efforts are unusually low; hence, the tax instrument will lead to particularly appropriate actions.
} 
atmosphere (with $\mathrm{CO}_{2}$ remaining in the atmosphere in excess of 100 years), changes in emissions in a specific period of time do not significantly alter atmospheric concentrations. Furthermore, climate change is itself a stock externality, that is, climate change is a function of the atmospheric stock of greenhouse gases, not the emissions per se at any point in time.

Newell and Pizer (2003) and others found that this implies that the marginal damage function (for any period) is relatively flat, which means that the marginal benefit function (of emissions reductions for that period) is also relatively flat, whereas the costs of emissions reductions are a function of contemporaneous policies. Hence, the current-period marginal benefits would have a smaller slope (in absolute value) than current-period marginal costs. Hence, the standard Weitzman analysis would suggest that the more efficient climate policy instrument under conditions of uncertainty about abatement costs will be a price instrument, such as a carbon tax, rather than a quantity instrument, such as cap-and-trade. ${ }^{23}$

The above comparison refers to the relative slopes of marginal benefits and marginal costs in a given time period, but the marginal damages of a unit of emissions during some time period (such as the current period) are equivalent to the present discounted value of the future stream of marginal damages, otherwise known as the social cost of carbon (Interagency Working Group on Social Cost of Carbon 2016; Weitzman 2014, 2017). In other words, with a stock pollutant, the marginal benefit of reducing emissions in the current period equals the present discounted value of the stream of reductions of current and future marginal damages. This is the appropriate comparison in the climate change context (Pizer and Prest 2019).

In a recent analysis, Karp \& Traeger (2018) utilize this comparison of the slopes of the current marginal cost of $\mathrm{CO}_{2}$ emissions reduction and the marginal benefits (avoided social cost of carbon) of a current unit of $\mathrm{CO}_{2}$ emissions reduction. They do this by applying to climate change policy the earlier analysis of the relative efficiency of price and quantity instruments in the presence simultaneous and correlated benefit and cost uncertainty (Stavins 1996). They note that an important source of uncertainty is technological change, which brings about positive correlation between uncertainty of abatement costs and uncertainty of (stock-related) damages, because technological change lowers current abatement costs, as well as future abatement costs, due to the persistence of the technology effect. Then, in their closed-loop (feedback) model, future policy makers will take these lower costs into account, and reduce future targeted emissions, and lower the expected future pollution stock in the atmosphere.

Hence, today's marginal damage function shifts downward, because the damages of emissions now are the discounted present value of the future stream of damages. On this basis, they find a positive correlation between uncertain benefits and uncertain costs. And, as

\footnotetext{
${ }^{23}$ At about the same time the paper by Newell and Pizer (2003) appeared, Hoel and Karp (2002) independently came to the same conclusion regarding stock externalities, but with a different analytical model. In their framework, the ranking of price versus quantity instruments also depends upon the discount rate and the rate of decay of the stock, with higher discount and decay rates favoring price instruments. They examined both open-loop policy (as did Newell and Pizer 2003), where price and quantity are set by the regulator and unchanged, and closed-loop (feedback) policy, where the price and quantity can be adjusted over time by the regulatory authority in response to new information. In the latter case, the relative efficiency of the two instruments also depends on the length of intervals between adjustments of prices and quantities by the regulator. They parameterized their models to examine the control of GHGs, and found - like Newell and Pizer (2003) - that prices (carbon taxes) are preferred to quantities (cap-and-trade). Also see Hoel and Karp (2001).
} 
previously demonstrated (Stavins 1996), such a positive correlation tends to favor a quantity instrument, compared with the finding from the usual relative slopes comparison which only considers cost uncertainty and ignores correlated benefit and cost uncertainty.

This analysis does not lead to an unambiguous finding favoring the quantity or the price instrument. Rather, the implication of the analysis by Karp and Traeger (2018) is that what was thought to be an unambiguous result from the stock externality application (Newell and Pizer 2003) of the Weitzman (1974) relative slopes rule becomes ambiguous, that is, it becomes an empirical question of the magnitude of the effect from Stavins (1996), compared with the basic effect of the relative slopes (Weitzman 1974; Hoel and Karp 2002; Newell and Pizer 2003), where the slopes compare current marginal costs with current marginal damages measured as the avoided social cost of carbon. The simple ranking of price over quantity instruments for the stock externality of climate change no longer holds. ${ }^{24}$

Karp and Traeger (2018) calibrate their dynamic model, drawing largely on the DICE model (Nordhaus 2013), and find that in many cases, the quantity instrument is superior to the price instrument. At a minimum, their analysis suggests that quantities can be (but are not necessarily) superior on efficiency grounds to price instruments for addressing climate change. In other words, the case for carbon taxes compared with cap-and-trade in the presence of uncertainty "is much weaker than commonly believed" (Karp and Traeger 2018). ${ }^{25}$

\subsubsection{Carbon Price Volatility}

Putting aside the issue of long-term benefit and cost uncertainty, another issue is shortterm price volatility. It is straightforward that the tax approach eliminates the potential for shortterm price volatility, which can surely exist under a cap-and-trade system. This is essentially an issue of two different types of endogeneity. Whereas prices are endogenous (and hence subject to fluctuation and volatility) under a cap-and-trade mechanism, emissions are endogenous under a carbon tax (Goulder and Schein 2013). Greater certainty about mitigation cost via a carbon tax (or a price collar in a cap-and-trade system - see below) reduces certainty about the quantity of emissions allowed (Aldy and Stavins 2012).

Such cost uncertainty (price volatility) in a cap-and-trade system can be an impediment to capital investment (Pindyck 2017; Metcalf 2019), and could undermine political support for climate policy and discourage investment in new technologies, as well as research and development (Aldy and Stavins 2012). From an economic perspective, it makes sense to allow emissions (of a stock pollutant) to vary from year to year with economic conditions that affect aggregate abatement costs. This happens automatically with a carbon tax, but with a cap and trade system, such temporal flexibility needs to be built in through provisions for banking and

\footnotetext{
${ }^{24}$ In a distinct, but related analysis, Pizer and Prest (2019) find that with policy updating (closed-loop model), if firms have expectations regarding future policy updates and if the quantity instrument is tradable over time, then the quantity instrument can be preferred on efficiency grounds to the price instrument, although their "main finding" is that the comparative advantage of one instrument versus the other depends more on firms' information and expectations about policy updates than on the relative slopes of marginal benefits and marginal costs.

${ }^{25}$ Given the very recent vintage of the analysis by Karp and Traeger (2018), I have placed the issue - performance in the presence of benefit and cost uncertainty - within the section on differences rather than the previous section on similarities.
} 
borrowing of allowances, which redefines the cap as a limit on cumulative emissions over a period of years, rather than a cap on annual emissions (Aldy \& Stavins 2012). Conversely, a carbon tax can employ measures to automatically adjust to meet some quantity target (Halfstead et al. 2017; Metcalf 2019), as I consider below when examining hybrid policy instruments.

\subsubsection{Interactions with Complementary Policies}

It is rarely, if ever, the case that carbon pricing instruments are considered as the sole policy to be used to address climate change. More often, carbon pricing - whether carbon tax or cap-and-trade - is considered as one of a suite of policy measures. In fact, if there are other market failures present, such as the principal-agent problem that affects decisions regarding adoption of thermal insulation in renter-occupied buildings or the public-good nature of information produced by carbon-friendly research and development activities, then there are solid economic arguments in favor of complementing a carbon-pricing regime with other regulatory policies (Schmalensee and Stavins 2017a). But if such additional market failures are not present (and if the complementary policies are not targeting sources outside of the scope of the carbon-pricing regime), then differences emerge between carbon taxes and cap-and-trade.

With a cap-and-trade regime, there are two possibilities of concern. One is that a complementary regulatory policy targets sources under the cap of the cap-and-trade system. The other is that a policy (of any type) is geographically nested within the area of a cap-and-trade system. In either of these situations, the results are threefold (Schmalensee and Stavins 2017a): (1) if the complementary policy is binding, there is no additional reduction in emissions due to the complementary policy, but rather a relocation of emissions to other sectors under the overall cap (100\% leakage), unless the complementary policy renders the allowance price floor binding; (2) with the binding complementary policy, marginal abatement costs are no longer equated among all sources, and so aggregate abatement costs are greater than without the additional policy; and (3) allowance prices are suppressed, raising concerns about the ability of the capand-trade system to encourage technological change (except in the sector directly regulated by the complementary policy). Hence, under these circumstances, the addition of a "complementary" policy increases abatement costs and lowers allowance prices, but does not on net - reduce emissions (Goulder and Stavins 2011).

When a carbon tax is paired with complementary policies, the emissions-leakage effect (and allowance price suppression) does not occur, and the complementary policy will serve to reduce emissions below the level that the tax alone would achieve. However, the combination of carbon tax and complementary policy is, like in the cap-and-trade case, not cost-effective, since marginal abatement costs are no longer identical for all sources. It would cost less to abandon the complementary policies, and rely instead on a boosted carbon tax rate to achieve the same degree of aggregate emissions reduction.

\subsubsection{Corruption and Market Manipulation}

With any policy there is a possibility of corruption of various kinds, including attempts by private firms to manipulate the market. For this reason, cap-and-trade systems require regulatory oversight. In the large European Union Emissions Trading System for GHG control, there was a single and quite significant case of theft of allowances in 2011 in the Czech 
Republic, as well as hacking of allowance accounts in a number of other countries (Metcalf 2019).

The parallel concern with a carbon tax system would presumably be tax evasion of one kind or another, a significant problem in many countries, but not of sufficient magnitude in the United States to present a major concern for a carbon tax (Metcalf 2019). However, much the same can be said of concerns for market manipulation in cap-and-trade systems within this country, since there has been only a single case of fraudulent activity reported (in the RECLAIM program), which was successfully prosecuted by the U.S. Department of Justice. In the large and ambitious California cap-and-trade system and the electricity-sector system in the Northeast (Schmalensee and Stavins 2017a), there have been no reported cases of attempted fraud. That said, it is difficult to contest the judgment of one analyst that in the United States "the risk of cybertheft from electronic registries in a cap and trade system is likely to present a greater problem than the risk of tax evasion in a carbon tax" (Metcalf 2019, p. 82).

\subsubsection{Transaction Costs}

A cap-and-trade system is likely to involve the trading of allowances among firms (unless the initial allocation matches the cost-effective-equilibrium allocation), and therefore there is the possibility of transaction costs, which increase aggregate compliance costs. More important, if transaction costs take the form of volume discounts, then with such decreasing marginal transaction costs, the equilibrium allocation through market activity is no longer independent of the initial allocation, removing a key political attraction of cap-and-trade (Stavins 1995). But historically, transaction costs - of any form - have not been empirically significant in implemented systems (Schmalensee and Stavins 2017a). The sulfur dioxide $\left(\mathrm{SO}_{2}\right)$ allowance trading system demonstrated that in properly designed systems, private markets can render transaction costs minimal (Schmalensee and Stavins 2013).

\subsubsection{Ease of Linkage with Policies in Other Jurisdictions ${ }^{26}$}

Linkage of policies across jurisdictions - connections among policy systems that allow emission reduction efforts to be redistributed across systems - is of great potential value because it: (1) can facilitate cost savings by allowing firms to take advantage of lower-cost abatement opportunities in other jurisdictions; (2) may improve the functioning of individual markets by reducing market power by enlarging the trading market, and reduce total price volatility by thickening markets; (3) can provide political benefits to linking parties by conveying a sign of momentum as political jurisdictions band together; (4) provides administrative economies of scale; and (5) allows for distributional equity among nations under existing international climate agreements (United Nations 2015) without sacrificing cost-effectiveness (Bodansky, Hoedl, Metcalf, and Stavins 2015; Mehling, Metcalf, and Stavins 2018).

Cap-and-trade systems generate a natural unit of exchange for linkage - allowances denominated in units of carbon content of fossil fuels or $\mathrm{CO}_{2}$ emissions. Hence, it would appear to be easier to link a domestic U.S. cap-and-trade system with other countries, particularly if they

\footnotetext{
${ }^{26}$ Also in the international domain, Weitzman $(2014,2017)$ has argued that negotiating a specific, single carbon price (if nations have already agreed to hold such a negotiation and abide by the negotiated price, where each country has one vote and accepts majority rule) is easier than negotiating a set of quantity limits.
} 
employ cap-and-trade approaches (Jaffe, Ranson, and Stavins 2010). Recent research has found, however, that through appropriate mechanisms, it is possible that linkage could be carried out between a domestic U.S. carbon tax systems and certain other policy instruments in other jurisdictions, although linkage of such heterogeneous policy instruments is considerably more challenging than the standard variety of linking two cap-and-trade regimes (Metcalf and Weisbach 2012; Bodansky, Hoedl, Metcalf, and Stavins 2015; Mehling, Metcalf, and Stavins 2018).

\subsubsection{Complexity and Administration}

The simplest cap-and-trade system will involve greater complexity than the simplest carbon tax. But more important than the relative complexity of the two approaches is the fact that greater complexity in design elements frequently translates into greater administrative burden for the system's implementation.

A cap-and-trade system requires government to track allowances (at the end of compliance periods), possibly hold auctions, and develop other necessary rules. These include rules to prevent fraud and abuse, although as noted above, issues of fraud have been rare with previous cap-and-trade applications. In contrast, a carbon tax is administratively simple and relatively straightforward to implement, given that the tax could incorporate existing methods for fuel-supply monitoring and reporting to the regulatory authority. It is reasonable to conclude that textbook applications of carbon taxes and cap-and-trade would yield greater administrative costs with the latter instrument (Goulder and Schein 2013).

Two possibly minor caveats are warranted. First, experience with cap-and-trade systems has demonstrated that the actual (marginal) costs of trading institutions have not been significant (Schmalensee and Stavins 2017a), although the fixed costs of setting up such institutions would presumably be greater than the fixed costs of setting up a carbon tax, since the latter could build on existing fossil fuel excise taxes. Second, experience also suggests that a simple tax proposal might become considerably more complex as it passes through the legislature. Whether a policy as important as a national carbon tax would turn out to be "simple" in its design and implementation is at least open to question. That said, it is also true that the simplest cap-andtrade regimes become more complex as they work their way through legislative processes.

\subsubsection{Political Resistance and Support for the Two Instruments}

A common thread throughout this paper is endorsement of the principle that realistic versions of alternative policies should be analyzed and compared (Hahn and Stavins 1992). In a recent presentation, Goulder (2019a, 2019b) goes further by suggesting that when comparing proposed climate policy instruments in an ex ante net present value analysis, it would be appropriate and desirable to weight the net benefits of each alternative by the probability of it being implemented within some period of time. These probabilities would presumably be dependent upon current and future political factors. ${ }^{27}$ In any event, this suggestion recognizes that issues of positive political economy may have normative dimensions, as well.

\footnotetext{
${ }^{27}$ In simple terms, as David Leonhardt has written in The New York Times, policies "are not efficient if they never pass" (Leonhardt 2019). However, making this analytical approach operational would require quantifying the probability of a specific policy being implemented (or rather, implementable) over some period of time, which
} 
In summary, Table 2 characterizes carbon taxes and cap-and-trade as being perfectly equivalent in regard to three attributes - incentives for emission reductions, aggregate abatement costs, and effects on competitiveness; nearly equivalent in regard to possibilities for raising revenue; similar in regard to costs to regulated firms, and distributional impacts; exhibiting some distinctions in regard to transaction costs; different in regard to performance in presence of uncertainty; and significantly different in regard to effects on carbon price volatility, interactions with complementary policies, potential for market manipulation, and complexity and administrative requirements.

\subsection{Hybrid Policy Instruments and a Policy Continuum}

Some remaining differences between carbon taxes and cap-and-trade can diminish with implementation, because hybrid policies that combine specific features of tax and cap-and-trade instruments can blur distinctions between the two. As already noted, the government can auction allowances in a cap-and-trade system, thereby reproducing many of the properties of a tax approach. In addition, mechanisms that reduce short-term price volatility and/or long-term price uncertainty in a cap-and-trade system bring it closer to a tax approach (Roberts and Spence 1976). These design elements include cost-containment mechanisms that place a cap or collar on allowance prices, banking that creates a floor under prices, and borrowing that provides flexibility similar to a tax. Hence, elements of design can foster symmetry of the two carbonpricing instruments.

The use of a safety-valve (hard price ceiling) or a price floor in a cap-and-trade system would appear to eliminate the key attribute that is strongly favored by environmental advocates, namely, lack of uncertainty regarding the quantity of emissions (Metcalf 2019), because a price ceiling is achieved through the provision of additional allowances, while a binding price floor results in fewer emissions than the stated cap level (Goulder and Schein 2013). However, in principle, the additional allowances the government offers for sale at the safety-valve price can come from an allowance reserve set aside for this purpose, or there can be borrowing from future allocations, so that total allowed emissions over time are unchanged, which is appropriate for the stock externality of climate change (Stavins 2008). Of course, the use of borrowing in a capand-trade regime raises a set of concerns that have prevented the adoption of this element in previous applications.

Likewise in a carbon tax system, certain elements of design can bring it closer to the properties of cap-and-trade. For example, emissions uncertainty with a tax can be reduced through a variety of means (Aldy et al. 2017), including: a formula for adjusting the tax (Hafstead, Metcalf, and Williams 2017); periodic government review (Aldy 2018); or dedicating some tax revenue for emission mitigation activities (Goulder and Schein 2013; Murray, Pizer, and Reichert 2017). Some of these approaches may be thought of as rendering a pure carbon tax a hybrid instrument, just as a price collar may be said to render a pure cap-and-trade system a hybrid instrument.

would be a function of current and future political factors. It is possible that quantifying those probabilities in a regulatory impact analysis could render the overall analysis less useful, because of the degree of uncertainty that would inevitably be associated with the respective politically-determined implementation probabilities. 
Thus, the dichotomous choice between carbon taxes and cap-and-trade can be a choice of design elements along a policy continuum (Weisbach 2010). Ultimately, the design of either instrument is very consequential, possibly more important than the choice between the two (Stavins 1997; Keohane, Revesz, and Stavins 1998; Goulder and Schein 2013; Goulder and Hafstead 2018).

\section{Positive Theory of Policy Instrument Choice}

In order to examine the most likely future choice in the United States between the two types of carbon-pricing instruments, this part of the paper applies the positive theory of policy instrument choice in the environmental realm to the choice between carbon taxes and cap-andtrade. First, we review the major components of positive theory in this realm, and then turn to an application of the model to the choice between taxes and trading.

\subsection{Components of Positive Theory}

Drawing on the metaphor of a political market, we can identify three components of a positive theory of policy instrument choice: political demand for a particular policy instrument; political supply of that policy instrument; and the equilibrium outcome in a legislature (Keohane, Revesz, and Stavins 1998).

\subsubsection{Political Demand for Policy Instruments}

The effective demand for policy instruments comes largely from firms and interest groups (Stigler 1971; Peltzman 1976, 1984; Becker 1983). Firms tend to demand those policy instruments that promise the highest profits - or lowest losses - from regulation, and some instruments augment profits through the generation of rents and the erection of entry barriers (Buchanan and Tullock 1975; Maloney and McCormick 1982). In addition, individual firms may support policy instruments that impose costs, as long as those costs are less than the industry average, giving them some competitive advantage (Oster 1982).

Environmental interest groups tend to exercise demand for policy instruments which: provide high confidence of low pollutant emissions levels; make benefits visible and may hide costs; offer lower compliance costs, if those lower costs mean more aggressive emissions targets; and keep Congressional authority in committees that are typically dominated by pro-environment members (Kelman 1981).

\subsubsection{Political Supply of Policy Instruments}

The political supply of policy instruments emanates from legislators (Kalt and Zupan 1984; Shepsle and Weingast 1984). In theory, legislators may start from a strong position of status quo bias (Kneese and Schulze 1975), but favor those policy instruments that provide (visible) benefits but not (visible) costs to their constituents (McCubbins and Sullivan 1984). Because politicians are risk averse, they prefer control over outcomes, particularly if their constituents are affected (Shepsle and Weingast 1984). But because constituents typically have very limited information, politicians may engage in symbolic politics, or exhibit demands that are consistent with their ideology, rather than their constituents' interests (Kalt and Zupan 1984). 


\subsubsection{Political Equilibrium}

The equilibrium of these forces of political supply and demand play out in what may be thought of as a political market. Policy instrument choice takes place in the legislature, where the key commodity is effective support, and the political currency is the accumulation of resources necessary for a legislator's reelection (Keohane, Revesz, and Stavins 1998). Exchanges occur among legislators, constituents, and interest groups, with the equilibrium yielding the legislative outcome.

\subsection{Positive Theory of the Choice Between Carbon Taxes and Cap-and-Trade}

Consistent with the theory, we can separate out demand-side and supply-side implications for the choice between carbon taxes and cap-and-trade. ${ }^{28}$

\subsubsection{Political Demand}

The historical opposition of private industry to pollution taxes results in part from the fact that with the simplest form of taxes, firms pay not only their compliance costs, but also the costs associated with tax payments for residual emissions (Buchanan and Tullock 1975), which will be some amount less than the full amount of tax payments, since some share is passed on to consumers. This also explains the historical and ongoing opposition of private industry to auctioning of allowances in cap-and-trade systems.

Rent generation and the erection of entry barriers helps explain why for many years when market-based instruments were used they most frequently took the form of cap-and-trade systems with freely-allocated allowances, where scarcity rents are conveyed to firms, and also provide entry barriers, since new entrants must purchase allowances from incumbent firms, making the rents sustainable (Keohane, Revesz, and Stavins 1998). On a global basis, this may help explain the ongoing preference from private industry for cap-and-trade mechanisms in the climate context.

Turning to the demand from environmental interest groups, there continues to be a strong preference for cap-and-trade over taxes, in part because these interest groups prefer policies that help obscure the costs, but make benefits transparent and visible (Stavins 1998), although in the United States this political difference has been significantly lessened, due to the successful tarnishing of the Obama administration's $\mathrm{CO}_{2}$ cap-and-trade proposal as "cap-and-tax" by Republican conservatives and coal-state Democrats. ${ }^{29}$ In addition, environmental interest groups may favor cap-and-trade over carbon taxes, because the former keeps the authority in environmental Congressional committees, where the advocacy groups have considerable influence, as opposed to the tax and finance committees, which are typically more conservative, and where the environmental groups typically have less influence (Kelman 1981; Metcalf 2019).

\footnotetext{
${ }^{28}$ For a very different approach to a theory of positive political economy of instrument choice in the context of climate change (which can help explain the recent prominence of the "Green New Deal"), see Driesen 2019.

${ }^{29}$ The "cap-and-tax" moniker may have derived from the fact that the Obama administration included in its first budget proposal included revenue to be obtained from a $\mathrm{CO}_{2}$ cap-and-trade program with auctioning of $100 \%$ of allowances.
} 


\subsubsection{Political Supply}

For politicians in the legislature, freely allocated allowances in a cap-and-trade system are typically favored over auctioned allowances or a tax, because no money is exchanged at the time of the initial allocation. On the other hand, the revenue from a tax or from auctioned allowances is attractive to the government (Stavins 1998), and may come to be a major political force on behalf of a future U.S. carbon tax.

A cap-and-trade policy gives legislators considerable control over the outcome for their constituents through the initial free allocation of allowances, because a cost-effective equilibrium is likely to be achieved independently of the initial allocation of allowances (Montgomery 1972), except under specific, limited circumstances. ${ }^{30}$ This independence property is of central political importance, and is the primary reason why cap-and-trade systems have been employed in representative democracies, where distributional issues are of paramount importance in mustering support for a policy. In principle, the government can set the overall emissions cap whether on the basis of economic efficiency or, more likely, some other grounds - and then leave it up to the legislature to allocate the available number of allowances among sources to build a constituency of support for the initiative without reducing the system's environmental performance or driving up its cost (Joskow and Schmalensee 1998). This should be contrasted with most public policy proposals - environmental or otherwise - for which the normal course of events is that the political machinations that are necessary to develop sufficient legislative support reduce the effectiveness of the policy and/or drive up its costs.

Thus, cap-and-trade leaves distributional issues up to politicians, and provides a straightforward means to compensate burdened sectors and other constituencies. Of course, this political advantage can be an economic disadvantage if it invites particularly harmful rentseeking behavior. In any event, the compensation associated with free distribution of allowances based on historical emissions can be mimicked under a tax regime through the assignment of specific tax exemptions (Goulder and Schein 2013), as noted previously.

Although there is a propensity of political processes under cap-and-trade to compensate sectors through free allowance allocations, a carbon tax would be sensitive to the same political pressures, and succumb in other ways, namely through sectoral or other tax exemptions that may reduce environmental achievement or drive up costs. Instead, a cap-and-trade system may be anticipated to lead to battles over the allowance allocation, but these do not raise the overall cost of the program nor affect its climate impacts (Montgomery 1972).

In terms of symbolic politics, policy makers working in the environmental realm seem to think in terms of pollution quantities, not prices. However, the political process may no longer favor announcing quantity goals (with conventional standards, cap-and-trade, or some other quantity-based approach), as it once did.

\footnotetext{
${ }^{30}$ This property can be violated under specific, but relatively uncommon conditions (Hahn and Stavins 2012), as well as in the presence of imperfect competition (Fowlie, Reguant, and Ryan 2016).
} 


\section{Empirical Evidence: What Experience Suggests About Future U.S. Climate Policy}

In this section I turn to an exploration of empirical evidence regarding first the normative aspects and then the positive aspects of the choice between carbon taxes and cap-and-trade. In other words, I seek to identify lessons that can be learned from previous and current applications of these two carbon-pricing instruments

\subsection{Empirical Evidence for Normative Assessment of Carbon Taxes and Cap-and-Trade}

Although more than 50 carbon-pricing policies have been implemented or are scheduled for implementation worldwide, including 26 carbon taxes and 25 emissions trading systems (Figure 1), I focus on a few of the more prominent examples of taxes and cap-and-trade that can offer the most useful lessons.

\subsubsection{Lessons from Experience with Cap-and-Trade Policies}

Among the most important applications of cap-and-trade in the United States have been the leaded gasoline phasedown (1982-1987), ${ }^{31}$ the sulfur dioxide $\left(\mathrm{SO}_{2}\right)$ allowance trading system (1994-2010), $\mathrm{NO}_{\mathrm{x}}$ trading (1998-2009), and the Regional Clean Air Incentives Market (1993present). In addition, two prominent U.S. cap-and-trade systems address $\mathrm{CO}_{2}$ emissions - the Regional Greenhouse Gas Initiative (2009-present), and California's system (2013-present); and the world's largest carbon-pricing initiative is the European Union Emissions Trading System (EU ETS, 2008-present). Table 3 summarizes the geographic scope, sectoral coverage, time duration, allowance allocation method, cost containment mechanisms, and environmental and economic performance of these seven important emissions trading systems.

There has also been rights trading for ozone depleting substances (ODS) in several countries during the ODS phasedown from 1991 to 2000 under the 1987 Montreal Protocol (Klassen 1999; Stavins 2003; U.S. Environmental Protection Agency 2014), as well as $\mathrm{CO}_{2}$ capand-trade systems in New Zealand, Japan, South Korea, Kazakhstan, Quebec, and other jurisdictions. Also, an international $\mathrm{CO}_{2}$ cap-and-trade system has been in place since 2008 under Article 17 of the Kyoto Protocol, but because the trading agents are nations, rather than firms, there has been little significant activity, an outcome that was anticipated (Hahn and Stavins 1999). As I discuss later, cap-and-trade systems are under development, planned, or proposed in many other jurisdictions (Schmalensee and Stavins 2017b).

Turning to lessons from these experiences, ${ }^{32}$ first, in terms of the basics, cap-and-trade has long since proven to be environmentally effective and economically cost-effective (lead phasedown, $\mathrm{SO}_{2}$ allowance trading ${ }^{33}$ ). For example, it has been estimated that $\mathrm{SO}_{2}$ trading reduced aggregate abatement costs by more than half, compared with a commensurate, welldesigned command-and-control approach (Metcalf 2019). The world's most important $\mathrm{CO}_{2}$ cap-

\footnotetext{
${ }^{31}$ The program was a tradable performance standard rather than a textbook cap-and-trade system.

${ }^{32}$ Lessons learned from experiences in industrialized countries are emphasized, both because these contexts are more relevant to the United States and because of the greater availability of reliable evaluations.

33 The policy experiences listed in parentheticals in this part of the paper refer to the sources of evidence for respective lessons.
} 
and-trade system - the European Union Emissions Trading System (EU ETS) - had its share of problems in its pilot phase (Metcalf 2019), but it has functioned essentially as anticipated since then (Ellerman, Convery, and Perthuis 2010). Relatively low allowance prices were a function of: (1) the degree of ambition of the cap; (2) the perverse effect of EU and member state "complementary policies," including those targeting renewable sources of energy and energy efficiency; and the 2008-2009 recession, which reduced energy demand. Of course, the lower allowance prices and fewer emissions reductions that occur with cap-and-trade during a recession are an economic virtue, that is, they are counter-cyclical, and do not unduly burden industry when it is fundamentally unnecessary and unwise to do so. As with the EU ETS and RGGI, downstream, sectoral programs have been commonly employed, although economy-wide systems have been shown to be feasible (AB-32).

Transaction costs have turned out to be low to trivial, particularly when compliance entities have been homogeneous (lead phasedown, $\mathrm{SO}_{2}$ allowance trading). In particular, the $\mathrm{SO}_{2}$ allowance trading system demonstrated that in properly designed systems, private markets can render transaction costs minimal (Schmalensee and Stavins 2013). In the context of climate policy, $\mathrm{CO}_{2}$ emissions trading programs have been limited in scope of coverage, in contrast with textbook, upstream trading of rights associated with the carbon content of fossil fuels (World Bank Group 2016).

It is clear from basic theory and validated by experience that a robust market requires a cap that is significantly below BAU emissions ( $\mathrm{SO}_{2}$ allowance trading, $\left.{ }^{34} \mathrm{RECLAIM}\right)$. Likewise, high levels of compliance require monitoring, reporting, and verification combined with significant penalties for non-compliance $\left(\mathrm{SO}_{2}\right.$ allowance trading). Also, it has been shown to be important for final rules to be established well before commencement of a system's first compliance period to avoid unnecessary price volatility $\left(\mathrm{SO}_{2}\right.$ allowance trading, $\mathrm{NO}_{\mathrm{x}}$ Budget, EU ETS).

Turning to specific elements of design, experience argues for systems that allow for a broad set of compliance alternatives, in terms of both timing and technological options. One of the most significant benefits of using carbon pricing - whether tax or cap-and-trade - is simply that technology and uniform performance standards are thereby avoided. Less flexible systems would not have led to the technological change that appears to have been induced by marketbased instruments (Ellerman and Montero 1998; Bohi and Burtraw 1992; Keohane 2003; Schmalensee and Stavins 2013; Calel and Deschezlepretre 2016), or the induced process innovations that have resulted (Doucet and Strauss 1994) in previous applications.

Provisions for banking of allowances have proven to be exceptionally important, as such inter-temporal trading has represented a large share of the realized gains from trade (lead phasedown, $\mathrm{SO}_{2}$ allowance trading). In contrast, the absence of banking provisions can lead to price spikes (RECLAIM) and price collapses (EU ETS). More broadly, a changing economy can render a cap non-binding (RGGI, EU ETS) or drive prices to excessive levels (RECLAIM). Hence, there is a distinct role in cap-and-trade systems for price collars, which reduce the risk of unanticipated allowance price changes and price volatility by combining an auction price floor

\footnotetext{
${ }^{34}$ For an analysis of how other government regulations (and some related judicial decisions) essentially eliminated the $\mathrm{SO}_{2}$ market beginning in 2006, see: Schmalensee and Stavins 2013.
} 
with an allowance reserve (RGGI, AB-32), a topic to which I return below. ${ }^{35}$ On the other hand, excessive constraints on offset use can lead to a thin market that fails to be effective for cost containment purposes (RGGI, AB-32).

Simplicity is important, and transparent formulae - including for allowance allocations - are difficult to contest or manipulate, particularly if rules are clearly defined up front, without ambiguity. By avoiding any requirements for prior government approval of individual trades, uncertainty and transaction costs are decreased (lead phasedown, $\mathrm{SO}_{2}$ allowance trading).

The allocation of allowances is inevitably a major political issue, because of the large distributional impacts that can be involved. A striking and important experience has been that free allowance allocation has proven to foster political support, although it means that the opportunity is foregone to cut the program's overall social cost by refunding revenues from auctioning allowances through cuts of distortionary taxes $\left(\mathrm{SO}_{2}\right.$ allowance trading, $\left.\mathrm{AB}-32\right)$. However, empirical experience has revealed that political pressures exist to use auction revenue not for the economist's favorite purpose of cutting distortionary taxes, but to fund new or existing government programs or relieve deficits (AB-32, RGGI). Indeed, cap-and-trade allowance auctions can and have generated very significant revenue for governments (RGGI, AB-32).

Another prominent political concern with cap-and-trade systems has been the possibility of emissions and economic leakage and related competitiveness impacts. In practice, leakage from cap-and-trade systems can range from non-existent (lead phasedown) to potentially quite serious (RGGI). It is most likely to be significant for programs of limited geographic scope, particularly in the power sector because of interconnected electricity markets (RGGI, AB-32). Attempts to reduce leakage and competitiveness threats through free allocation of allowances per se does not address the problem (EU ETS), but an output-based updating allocation - in principle - can do so (AB-32).

Carbon pricing (through cap-and-trade or taxes) may be said to be necessary to address climate change, but it is surely not sufficient, due to the limited sectoral scope of some carbon pricing regimes, and - more broadly - due to the presence of other market failures that inhibit the perfect functioning of markets. Hence, there can be an appropriate role for complementary policies. But actual suites of so-called "complementary policies" have frequently conflicted rather than complemented by addressing emissions under the cap, thereby relocating rather than reducing emissions, driving up abatement costs, and suppressing allowance prices (Organization for Economic Cooperation and Development 2011). This perverse situation has characterized two of the most prominent applications of cap-and-trade in the climate policy context (AB-32, EU ETS).

The degree of perverse interaction of a complementary policy with a cap-and-trade system within which it is nested can be characterized by the difference in marginal abatement costs between the cap-and-trade system and the complementary policy. In the case of California,

\footnotetext{
${ }^{35}$ A laboratory experiment by Holt and Shobe (2016), which compared price collars, as used in RGGI and AB-32, with quantity collars (modeled after the EU ETS Market Stability Reserve), found that the price collar was superior to the quantity collar in terms of reducing allowance price volatility and increasing efficiency.
} 
these marginal costs are known, because they are represented by the allowance price in the AB32 cap-and-trade system, and by a separate allowance price under a distinct trading system that operates in the state's refinery-based Low Carbon Fuel Standard (LCFS). In February, 2019, AB-32 allowances were trading at about \$16/ton, while LCFS allowances were trading at approximately \$200/ton (Lithgow 2019f), representing a dramatic departure from an overall system of cost-effective emissions reduction.

These perverse interactions, frequently characterized as the "waterbed effect" in the European context (Fankhauser, Hepburn, and Park 2010; Perino 2018), may be partially alleviated by planned reforms employing "market stability reserves" in the EU ETS, California, and RGGI (Edenhofer, et al. 2017; Perino, Ritz, and van Benthem 2019).

\subsubsection{Lessons from Experience with Carbon Taxes}

In contrast with the history of cap-and-trade systems, the lion's share of implemented pollution taxes have been focused on $\mathrm{CO}_{2}$ (or related energy generation), including 26 carbon taxes identified by the World Bank as of 2018. As with cap-and-trade, I focus on the most prominent applications - carbon taxes that are set at particularly high levels in several northern European countries, and the more recent carbon tax in British Columbia.

\subsubsection{Northern European Carbon Taxes}

European carbon taxes have frequently been elements of broader energy and excise tax reform initiatives, as opposed to singular focus on reducing $\mathrm{CO}_{2}$ emissions (Murray and Rivers 2015). The systems have had different scopes of coverage, different tax rates, and many are coincident with - if not linked with - the EU ETS, making it difficult to assess impacts (Murray and Rivers 2015). In the 1990s, several northern European countries imposed carbon taxes to limit their greenhouse gas emissions as part of broader tax policies.

Norway implemented a carbon tax in 1991 that varied in its level across sectors of the economy, despite the fact that cost-effective abatement would call for a uniform tax. By 1999, facilities using coal paid \$24/ton of $\mathrm{CO}_{2}$ for coal for energy purposes and \$19/ton for coal for coking purposes (Bruvoll and Larsen 2004), but these activities were completely exempted from the carbon tax beginning in 2003. In the transportation sector, by 2009, the Norwegian carbon tax was $\$ 58 /$ ton of $\mathrm{CO}_{2}$ on gasoline and $\$ 34 /$ ton on diesel. In 2009, the carbon tax applied to about $55 \%$ of Norwegian greenhouse gas emissions, while an emission trading scheme linked to the EU ETS covered an additional $13 \%$ of emissions. ${ }^{36}$ In 2003, Norway also introduced a tax of $\$ 33 /$ ton of $\mathrm{CO}_{2}$-equivalent on HFCs and PFCs, to slow the growth rate of these potent greenhouse gases.

Sweden implemented a carbon tax of \$33/ton of $\mathrm{CO}_{2}$ in 1991 as a part of a fiscal reform that cut high income tax rates (Speck 2008). The carbon tax has since increased to approximately $\$ 120 /$ ton of $\mathrm{CO}_{2}$ (based on the February, 2019 exchange rate). When the carbon tax was implemented, Sweden - as a relatively small, open economy - reduced its general energy tax on many of the sources bearing the carbon tax; and refineries, steel, and other primary

\footnotetext{
${ }^{36}$ Greenhouse gas emissions in the offshore oil sector, representing $24 \%$ of Norway’s emissions, are covered by
} both a (lower) carbon tax and the emission trading scheme. 
metal industries received exemptions from the carbon tax (Daugjberg and Pedersen 2004). In addition, those industries covered by the EU ETS were exempted from the carbon tax, but in 2018, these exemptions were relaxed. ${ }^{37}$ The tax has generated considerable revenue for the general budget, as there is no earmarking of tax revenues in Sweden (Government Offices of Sweden 2019). However, because of its (fully intended) impacts, revenues from the tax on heating fuels, for example, have fallen due to decreased use and consequent erosion of the tax base.

Denmark implemented a carbon tax of about $\$ 18 /$ ton of $\mathrm{CO}_{2}$ in 1992, and reduced the tax to $\$ 17 / \mathrm{tCO}_{2}$ in 2005, where it has remained (Speck 2008; World Bank Group 2018). Manufacturing sectors face lower tax rates, up to $90 \%$ below the standard rate, depending on their energy intensity.

Finland has imposed a general tax on energy coupled with a surtax based on the carbon content of the energy since 1997. Like other northern European nations, Finland lowers its carbon tax for industries covered by the EU ETS. Since 2008, the carbon surtax has been about $\$ 28 /$ ton of $\mathrm{CO}_{2}$, although natural gas faces half this rate (World Bank Group 2018).

Some of the carbon taxes in northern Europe are at the highest levels of any carbon prices worldwide (Figure 1), although implementation has yielded significant variations in the effective tax per unit of $\mathrm{CO}_{2}$ across fuels and industries within each country, contrary to the cost-effective prescription of a common price on carbon. In addition, fiscal cushioning to the carbon taxes - by adjustments to pre-existing energy taxes - and to the EU ETS - by adjustments to pre-existing carbon taxes - is common, especially for those industries expressing concerns about their international competitiveness (Aldy and Stavins 2012). Nevertheless, these countries were the first to demonstrate that carbon taxes could be employed to reduce greenhouse gas emissions, while raising revenue to finance government spending or lower other tax rates (Organization of Economic Cooperation and Development 2001). Unfortunately, there is little empirical evidence of the emissions impacts of these taxes.

\subsubsection{British Columbia Carbon Tax}

The Canadian province of British Columbia has had in place since 2008 a carbon tax that comes closest to the version of an ideal carbon tax typically recommended by economists (Metcalf 2019). As such, it has been characterized - like the U.S. SO $\mathrm{S}_{2}$ allowance trading system - as "a grand policy experiment” (Stavins 1998; Murray and Rivers 2015). The tax is one part of British Columbia's plan to reduce provincial GHG emissions by 33\% by 2020 (British Columbia 2007). The carbon tax is intended to be economy-wide (covering approximately $70-75 \%$ of emissions).

\footnotetext{
${ }^{37}$ Since January 1, 2018, previously exempted emissions from combined heat and power plants that are also covered by the EU ETS are being taxes at $11 \%$ of the full tax rate. The tax level for other heat production covered by the EU ETS increased from $80 \%$ to $91 \%$ of the full rate, while industrial facilities covered by the EU ETS are still entirely exempt from the carbon tax. In addition, since January 1, 2018, the carbon tax rate on industrial facilities not covered by the EU ETS became aligned with the general tax rate. Prior to this date, a lower tax rate was applied to these facilities (World Bank Group 2019).
} 
It began at $\$ 7.50$ per ton of $\mathrm{CO}_{2}$-equivalent emissions in 2008 , increasing by $\$ 3.75$ per year, now amounts to $\$ 27 /$ ton, ${ }^{38}$ and is scheduled to reach $\$ 38 /$ ton in 2021 . The tax is collected upstream at the wholesale level (fuel distributors), based on the carbon content of fuels (Duff 2008), and, according to Metcalf (2019, p. 50), covers "carbon emissions of all hydrocarbon fuels burned in the province." Exemptions from the tax include: fuels exported from British Columbia; ${ }^{39}$ fuels used by aviation and shipping into or out of the province; operations and fuels used in agriculture (since 2012); all non-fossil-fuel GHG emissions, including from industrial processes, landfills, forestry, and agriculture; and methane emissions from the production and transmission of fossil fuels.

Originally, by law, $100 \%$ of the tax revenue was to be refunded through tax cuts to businesses and individuals, with low-income individuals further protected through a targeted tax credit. But, over time, the policy has evolved from using revenues to cut distortionary taxes to more focused use of specific tax cuts for specific sectors and locations (Murray and Rivers 2015). That said, combining general tax cuts and those targeted to specific sectors, companies, and locations, the current disposition of tax revenues is: $50 \%$ to business tax rate reductions and corporate income tax credits; $23 \%$ to personal income tax cuts; and 25\% to equal lump-sum rebates to households (Goulder and Hafstead 2018). According to an analysis by Beck et al. (2015), when taking into account both its use-side and source-side impacts (see above), the British Columbia carbon tax turns out to be progressive in its distributional impacts, even before considering the consequences of specific uses of revenue.

In terms of its performance, empirical evidence is unclear. One estimate is that the tax policy has reduced the province's $\mathrm{CO}_{2}$ emissions by $5-10 \%$, with little negative impact on the economy (Metcalf 2019), but unknown emissions leakage (Murray and Rivers 2015). But other research has questioned whether emissions have been reduced (Pretis 2019). On the other hand, the government has estimated that by 2020, the carbon tax will reduce British Columbia's $\mathrm{CO}_{2}$ emissions by approximately 3 million tons annually.

\subsubsection{Lessons from Experience with Hybrid Policy Instruments}

As discussed above, hybrid policies that combine features of tax and cap-and-trade can blur distinctions between the two. Empirical experiences with cap-and-trade systems suggests a trend of greater use over time of auctioning of allowances, as in the California AB-32/398 system, the Regional Greenhouse Gas Initiative (RGGI), and the European Union Emissions Trading System (EU ETS).

The blurring of the two approaches can become even more pronounced with the use of cost-containment elements in cap-and-trade systems, which reproduce many of the properties of a tax approach, as do mechanisms that reduce short-term price volatility and/or long-term price uncertainty in a cap-and-trade system. Banking provisions have been common in all $\mathrm{CO}_{2}$ capand-trade systems (and nearly all cap-and-trade systems for other pollutants), but borrowing

\footnotetext{
${ }^{38}$ The April 2019 exchange rate has been used to convert Canadian dollars to U.S. dollars.

${ }^{39}$ Note that virtually all of the coal mined in British Columbia is exported (Murray and Rivers 2015). About $90 \%$ of the province's coal production is steel-producing coking coal. The province does not use coal for power generation.
} 
provisions have only been present implicitly in the form of compliance periods that have ranged from one to five years.

The California system as well as RGGI have employed safety-valve prices, $\$ 10$ in the case of RGGI, and greater than \$50 in the California system. In fact, both systems now employ price collars, combining an auction price floor with a price that triggers availability from an allowance reserve. However, these approaches provide a "soft ceiling" on prices (or a soft price collar), because there is a finite supply of allowances in the reserve. Going forward, California's post-2020 system will include a hard ceiling on prices, in which there will be no limit on the supply of allowances available at a specified, escalating price level (Schatzki and Stavins 2018b).

\subsection{Empirical Evidence for Positive Assessment of Carbon Taxes and Cap-and-Trade}

Some analysts have contended that because the differences in outcomes with the two approaches need not be very great, the key questions to address in deciding between these two policy approaches are which is more politically feasible and which is more likely to be well designed (Furman, Bordoff, Deshpande, and Noel 2007). To some degree, responses to the first question could be provided by the political revealed preference of individual countries. The number of $\mathrm{CO}_{2}$ cap-and-trade and carbon tax systems around the world is about the same (World Bank Group 2018).

\subsubsection{Cap-and-Trade Experience}

Rather than counting the number of systems, the relative significance of the two approaches can be assessed to some degree by observing the relative mass exhibited in Figure 1, which provides a sense of scope of coverage multiplied by stringency (carbon price). ${ }^{40}$ The world's most significant carbon-pricing regime is surely the European Union Emission Trading Scheme (EU ETS).

A major factor behind the choice of that instrument by the European Commission was the perceived success of the U.S. $\mathrm{SO}_{2}$ allowance trading program. However, another factor said to have influenced the choice of cap-and-trade over a tax approach was the fact that fiscal measures - such as a carbon tax -require unanimity in the Council of the European Union, whereas most other measures - including cap-and-trade - require only a majority (Metcalf 2019). It is for this same reason that an upstream (and hence, economy-wide) system was not employed, because it was thought that since it would appear downstream like a tax, it might require unanimity in the EU Council.

Going forward, other evidence of political revealed preference for emissions trading comes from China, where after much reflection on cap-and-trade and carbon tax theory, as well

\footnotetext{
${ }^{40}$ In addition to these existing cap-and-trade systems, there are other systems in various stages of planning (or at least proposing) in Canada, Chile, China, Costa Rica, Japan, Mexico, Taiwan, Thailand, Turkey, Ukraine, and Viet Nam (Schmalensee and Stavins 2017b), as well as at the sub-national level in the United States, including New Mexico (Lithgow 2019c), New Jersey, Oregon (Lithgow 2019e), and Washington (Lithgow 2019a). There are carbon tax proposals at various stages in Brazil, Ivory Coast, and the Netherlands (World Bank Group 2018), plus sub-national proposals in Maine (Lithgow 2019b), Massachusetts, New Hampshire (Lithgow 2019d), and Washington.
} 
as the experience of its six pilot provincial and municipal emissions trading systems, the government chose to proceed with a national emissions trading system, although it should be noted that it is not cap-and-trade per se, but rather a national set of sectoral tradable performance standards (Goulder and Morgenstern 2018; Pizer and Zhang 2018). ${ }^{41}$

In December, 2018, nine northeastern states plus the District of Columbia announced the Transportation and Climate Initiative (TCI), intended to reduce GHG emissions from the transportation sector, with the design of the mechanism to be completed by the end of 2019. The announcement referred to the development of a "market-based policy," with much of the original thrust emphasizing the potential use of a tax mechanism for transportation fuels, to complement the cap-and-trade instrument used by the RGGI states in the electricity sector. However, by early February, 2019, indications were that "officials will gravitate towards a cap-and-trade programme for the final design, as all jurisdictions except Pennsylvania and Washington, D.C. have experience with that structure via RGGI” (McGraw 2019).

At the same time, Oregon is poised to enact in 2019 an economy-wide $\mathrm{CO}_{2}$ cap-and-trade system, patterned after the California system, with which it would link via the Western Climate Initiative (Schatzki and Stavins 2018a; Burtraw et al. 2019). The system lays out in a 98-page "Clean Energy Jobs" bill how the system - beginning in 2021 - would achieve emission reduction goals of $45 \%$ by 2035 and $80 \%$ by 2050, relative to 1990 levels (Climate Xchange 2019). Electricity generators and importers, natural gas utilities, petroleum-product distributors (including gasoline and diesel fuel), and large point sources will be included under the declining cap. Emissions from energy used out of state, aviation, watercraft, and rail transportation will be exempted. An increasing share of allowances is to be auctioned over time, starting with $60 \%$ at the program's launch in 2021, with most funds directed to climate-related programs. Emissionsintensive trade-exposed (EITE) industries receive allowances through an output-based updating allocation. In addition, New Jersey is preparing to join RGGI.

\subsubsection{The Limits of Cap-and-Trade Experience and the Promise of a U.S. Carbon Tax}

Past may not be prologue, at least not in the United States. What has been the dominant political revealed-preference for emissions trading over pollution taxes may not hold for future applications at the national level to GHG emission reductions. ${ }^{42}$ Since the successful

\footnotetext{
${ }^{41}$ China's new Ministry of Ecology and Environment circulated a work plan in April, 2019, for its emissions trading system (ETS), originally "launched" in December, 2017. A trial ETS for the electricity-generation sector is scheduled to commence in November, 2019, with the actual market - covering $80 \%$ of China's generators, which emit about 3 to 3.5 billion tons of $\mathrm{CO}_{2}$ annually - expected to start in 2020. Over the subsequent five years, the plan is to bring petrochemicals, chemicals, building materials, steel, non-ferrous metals, paper production, and aviation sectors under the system. Initially, allowances will be distributed freely, with auctioning commencing sometime between 2020 and 2025. If China meets this plan, the ETS will cover about 7 billion tons of $\mathrm{CO}_{2}$ emissions annually, making the system more than four times the size of the EU ETS, currently the world's largest (Reklev 2019). In the longer term, it is anticipated that the TPS system will evolve into a mass-based cap-and-trade system sometime after 2025.

${ }^{42}$ However, at the sub-national level in the United States, the only two significant carbon-pricing systems are the cap-and-trade policies in California and the northeast. In the state of Washington, the Senate blocked a cap-andtrade bill in 2015, then voters rejected carbon tax ballot initiatives - in 2016 with revenues directed to cutting other tax rates, and in 2018 with revenues directed to environmental programs and projects. None of three climate bills introduced early in 2019 in Washington involve carbon pricing of any kind (Kagubare 2019), although a cap-andtrade proposal is again circulating in the state Senate (Lithgow 2019a).
} 
demonization in 2009 of cap-and-trade as "cap-and-tax" by opponents of the Waxman-Markey legislation (H.R. 2454, the American Clean Energy and Security Act of 2009), the political advantage held by this instrument (namely, doing a better job of obscuring cost than did a tax) may have been lost, at least for the foreseeable future for national climate legislation (Schmalensee and Stavins 2013, 2017).

Beyond that, as I discuss below, there is clearly increasing interest within the policy community - and even within Congress - in the possibility of using a Federal carbon tax to reduce $\mathrm{CO}_{2}$ emissions. This heightened activity includes: the Market Choice Act of July, 2018, which would have imposed a $\$ 24 /$ ton carbon tax, with $70 \%$ or the revenue going to infrastructure projects; the Energy Innovation and Carbon Dividend Act of November, 2018, which provided a \$15/ton carbon "fee," with the revenue rebated to households; and the even more prominent bipartisan proposal from the Climate Leadership Council, endorsed by some leading Republican economists and former senior government officials (Akerloff et al. 2019). On the other hand, the most prominent climate proposal in the current Congress is surely the "Green New Deal,"43 which is noticeably silent about, if not hostile towards any kind of carbon-pricing initiative. In the meantime, there may be positive political economy lessons to be learned from British Columbia's experience with its carbon tax system. ${ }^{44}$

\subsubsection{Political Economy of the British Columbia Carbon Tax}

The successful enactment in British Columbia of its carbon tax has been attributed to the "confluence of political conditions ripe for carbon taxation" (Harrison 2013; Datla and Lee 2016), including: (1) availability of untapped hydroelectric potential as an important source of electrical power; (2) a strongly environmentalist electorate combined with a surge in public concern about climate change (as with California's move to a $\mathrm{CO}_{2}$ cap-and-trade system); (3) a right-center majority government that had the trust of the business community (as with the George H. W. Bush administration's push for the $\mathrm{SO}_{2}$ allowance trading program); and (4) a committed leader with the institutional capacity to pursue his personal policy preferences - the Premier made the decision about a carbon tax (Harrison 2013). ${ }^{45}$

The political economy of this carbon tax has changed over time. Public opinion was opposed to the tax when it was introduced in 2008 , with $60 \%$ somewhat or strongly opposed. But

\footnotetext{
${ }^{43}$ The "Green New Deal” proposal includes a set of economic stimulus objectives and programs intended to address climate change and economic inequality (U.S. House of Representatives 2019). A political advantage of noncarbon-pricing approaches is that - like cap-and-trade in the past - they can hide the economic costs of the policies (Leonhardt 2019).

${ }^{44}$ The unusually high carbon taxes that exist in Sweden - and to lesser degrees in the other Scandinavian countries may have less to offer for relevant political economy lessons for the United States, because in Sweden, high taxes exist, in general, and are well accepted, with citizens enjoying state-funded access to services such as child care and education. High taxes may work in the region because the notion of state welfare is so deeply rooted in the culture. Therefore, I focus on potential positive political economy lessons for the United States from the British Columbia experience.

${ }^{45}$ To a degree not frequently recognized by academic studies, successful policy initiatives can at least partly be attributed to healthy doses of chance that have placed specific persons at critical moments into key positions in government and the broader policy community (Stavins 1998).
} 
by 2015 , only $45 \%$ of the surveyed population was somewhat or strongly opposed (Murray and Rivers 2015). This increased public acceptance may partly have been due to the perception that emissions had been reduced without severe economic impacts (Harrison 2013). In addition, the British Columbia government had become reliant on the revenue.

Over time, political pressures have caused the system to evolve from one where revenues were used broadly to cut distortionary taxes to a system that was considerably more focused on the use of tax cuts to favor specific sectors (including the motion picture industry), and for payments and tax cuts for northern rural households and low-income populations (Murray and Rivers 2015). "What began as use of carbon tax revenues for general tax reform to reduce distortions and promote economic growth (straight out of the economist's playbook) appears to have evolved into a system with some 'industrial policy' objectives for promoting certain sectors” (Murray and Rivers 2015, p. 7).

Interestingly, the policy is no longer revenue-neutral. From 2008 through 2015, the carbon tax generated $\$ 4.6$ billion of revenue, with tax cuts exceeding $\$ 5.3$ billion over the same period (Plumer 2010; Murray and Rivers 2015). The tax reached $\$ 27$ in April, 2018, and is scheduled to increase annually by $\$ 3.75$ until the rate reaches \$38/ton of $\mathrm{CO}_{2}$-equivalent in 2021. However, according to one analysis, there is likely to be continuing political pressure for exemptions for trade-exposed industries (Harrison 2013). Experience with concessions that have been granted to local governments, rural voters, and farmers may be cause for concern in this regard (Harrison 2013).

It is probably fair to say that political pressures can drive up the social costs of both carbon-pricing instruments, with incentives sometimes working against auctioning of allowances in cap-and-trade systems, and a variety of pressures working against employing cost-effective cuts of distortionary taxes in carbon tax systems. ${ }^{46}$

\section{Conclusions: The Path Ahead}

At the outset, I posed two questions. How do the two major approaches to carbon pricing compare on relevant dimensions? And which of the two approaches is more likely to be adopted in the future in the United States?

\subsection{Does Either Carbon-Pricing Instrument Dominate in Normative or Positive Terms?}

In principle, either carbon-pricing instrument could be used in a national system to achieve meaningful reductions of $\mathrm{CO}_{2}$ emissions, such as the 2025 target of 26-28\% below the 2005 level, expressed in the U.S. NDC under the Paris Agreement (Chen and Hafstead 2018). When carbon taxes and carbon cap-and-trade systems are designed in ways that make them truly comparable, their characteristics and outcomes are similar, and in some cases fully equivalent (normatively), in terms of their: emission reductions; abatement costs; possibilities for raising

\footnotetext{
${ }^{46}$ It is possible that additional carbon-pricing systems will be forthcoming at the provincial level in Canada. Four provinces that had resisted the Federal government's carbon-pricing mandate - Ontario, Saskatchewan, Manitoba, and New Brunswick - became subject to the Federal government's backstop carbon tax on April 1, 2019. The mandate is now being subjected to legal challenge, but all of this may become moot, depending upon the outcome of the national general election on October 21, 2019.
} 
revenue; costs to regulated firms when revenue-raising instruments are employed; distributional impacts; and effects on competitiveness.

On some other dimensions, there can be real differences between the performance of these two approaches. Some of these dimensions favor carbon taxes and some cap-and-trade, and most depend on respective design elements. In particular, the tax approach is clearly favored by three elements: complexity and administrative requirements; interactions with complementary policies; and effects on carbon-price volatility. Cap-and-trade is favored by its ease of linkage with policies in other jurisdictions; and possibly by its anticipated performance in the presence of uncertainty. However, neither transaction costs nor the potential for market manipulation with cap-and-trade appear to be particularly important in the U.S. context.

Thus, the available evidence supports the normative conclusion that neither approach dominates the other, and any overall ranking would depend upon the weights given to the various dimensions of difference (Goulder and Schein 2013; Goulder and Hamstead 2018), as well as the relative probability of good design.

Much the same can be said in the positive political economy domain: there is decidedly mixed evidence regarding which of the two carbon-pricing approaches (if either) is more likely to be adopted at the national level in the United States in the future. Thus, there is not a strong case for the superiority of taxes or trading, normatively or positively, and differences in performance that are a function of specific design of the two instruments dominate differences in the performance of the instruments themselves.

Two major conclusions therefore stand out. One is that the specific designs of carbon taxes and cap-and-trade systems may be more consequential than the choice between the two instruments. Many differences fade with specific implementations, and what appears to be the dichotomous choice between two distinct policy instruments often turns out to be a choice of design elements along a policy continuum. The other conclusion that stands out is that issues of positive political economy frequently have normative dimensions, and normative attributes have important implications for political prognosis.

All of this serves as a reminder of the importance of avoiding comparisons of two policy instruments where one is idealized and the other realistic; rather, comparisons are best made between idealized versions of two instruments, or - better yet - realistic versions of both (Hahn and Stavins 1992). This is consistent with the notion of comparing proposed climate policy instruments by weighting the net benefits of each by the probability of it being implemented within some time period, an approach which would essentially merge the normative and positive domains. National policy instruments that appear impeccable from the vantage point of Berkeley, Cambridge, Madison, or New Haven, but consistently prove infeasible in Washington, D.C., can hardly be considered “optimal” (Stavins 2012).

\subsection{The Virtue of Simplicity and the Challenge of Politics}

It may be reasonable to stipulate (as the lawyers say) that in regard to relative simplicity, carbon taxes have the upper hand over cap-and-trade. But real carbon taxes "are among the least used climate policy instruments" (Carattini et al. 2017), with only twenty countries and two Canadian provinces having implemented carbon taxes as of 2018, with South Africa now having delayed implementation. Also, carbon tax proposals have been undone, reversed, or simply 
failed - sometimes at very advanced stages politically - such as in France and Switzerland in 2000, Australia in 2014, and the State of Washington in 2016 and 2018 (Carattini et al. 2017; Anderson, Marinescu, and Shor 2018). Cap-and-trade has not fared much better (Figure 1), having failed at the national level in the United States during the Obama administration (although at the sub-national level, cap-and-trade systems are poised to be launched in 2019 in three states).

This track record can be compared with the 176 countries that had renewable energy policies and/or energy efficiency standards, and another 110 national and sub-national jurisdictions with feed-in tariffs, as of 2016 (Carattini et al. 2017). So, thinking about how to make carbon taxes or cap-and-trade more politically acceptable may be a critical step for more effective climate policy action.

\subsection{Can Carbon Pricing be Made More Politically Acceptable?}

Can carbon taxes or cap-and-trade be made more acceptable by designing them in ways that respond to voter concerns? This is a particularly important question, given the considerable ambiguity regarding the normative superiority of either of these instruments, and the reality that specific elements of design can minimize, if not eliminate, remaining differences.

Survey and other evidence indicate that a set of public perceptions - at least some of which are inaccurate - are primary factors behind aversion to carbon taxes, including: the personal costs are too great; the policy is regressive; it could damage the economy; it will not discourage carbon-intensive behavior; and governments just want to increase their revenues (Carattini et al. 2017). ${ }^{47}$ This suggests that one way to improve public acceptability could be through better informing the public about the real nature and consequences of carbon-pricing policies.

Another way to increase public acceptability could be through judicious policy design. Several routes might be employed to make carbon taxes or cap-and-trade more politically acceptable, while departing from what may be first-best design. One approach would be to phase in taxes/caps over time, since a lower carbon price is presumably more politically acceptable, and as aversion may abate over time, prices can be increased (Carattini 2017). This is the route that California and British Columbia have taken with their respective carbon-pricing policies. A gradual phase in also reduces the stranded asset problem (Rozenberg, et al. 2019), even if the outcome is less effective in the short run and hence less efficient. There is a risk that the carbon price would become stuck at too low a level, so a commitment device may be appropriate, such as making the emissions cap or tax rate trajectory part of legislation, as was done with the $\mathrm{SO}_{2}$ allowance trading program and the British Columbia and Swedish carbon taxes.

A second, very important design modification that would frequently depart from the firstbest (most efficient) design would be to earmark carbon tax or auctioned allowance revenue to finance additional climate mitigation (Amdur, Rabe, and Borick 2014; Carattini et al. 2017; Kotchen, Turk, and Leiserowitz 2017). This is in contrast to economists' first-best use of treating carbon tax proceeds as part of general revenues, so that the tax system as a whole can be

\footnotetext{
${ }^{47}$ This list of factors as well as the potential means of addressing these through modifications of carbon tax design I subsequently describe are drawn from Carattini et al. 2017, and a large number of other studies cited therein.
} 
optimized, such as through cutting distortionary taxes. There is, in fact, substantial evidence of voter preference for such earmarked use of revenues, with particular attraction to using revenue for low-carbon research and development, and subsidies to promote deployment. The former, at least, can be part of an efficient portfolio of complementary climate policies, due to the separate market failure of the public good nature of information. Of course, in principle, earmarking could be phased down over time.

A third and final design modification that departs from a first-best approach is to use revenues for fairness purposes, such as with a progressive revenue-neutral carbon tax or cap-andtrade system with lump-sum rebates of tax (or auction) revenue or rebates more targeted to cushion impacts on low-income or other particularly burdened constituencies (Amdur, Rabe, and Borick 2014; Carattini et al. 2017), rather than recycling carbon tax revenue through cuts in distortionary taxes (Goulder and Hafstead 2018; Metcalf 2019). A diverse set of surveys indicate voter support for using carbon-pricing revenue to ease impacts on low-income households (Carattini et al. 2017). Proposals from very different political perspectives have favored this approach, using so-called carbon dividends with carbon taxes or as part of a "cap-

and-dividend" trading system (Boyce and Riddle 2007; Sedor 2015; U.S. House of Representatives 2018; Akerlof et al. 2019; Harder 2019).

Survey evidence does not indicate support from the general public for using revenue to cut distortionary taxes. In fact, surveys in Denmark, Germany, the United Kingdom, and other countries have found cutting other taxes to be the least popular strategy for the use of revenues (Carattini et al. 2019). Why might this be? It could be that voters do not understand the logic of the "double dividend" (Goulder 1995), which can come from cutting these other taxes. Or it may be a simple lack of trust of politicians and government; that is, doubt that governments will actually cut the other taxes, or fear that the "wrong people" would benefit. In general, survey evidence indicates that public support both for carbon taxes and for carbon cap-and-trade is linked with proposed uses of revenue (Amdur, Rabe, and Borick 2014; Mills, Rabe, and Borick 2015; Kotchen, Turk, and Leiserowitz 2017).

\subsection{Can the Rejection of National Carbon Cap-and-Trade Help Carbon Tax Proposals?}

Political polarization in the United States - which began some five decades ago and accelerated after 1990, has decimated what had long been the key source of political support in the Congress for environmental and energy action, namely, the middle, including both moderate Republicans and moderate Democrats (Stavins 2011; Schmalensee and Stavins 2013). Whereas Congressional debates about environmental and energy policy had long featured regional politics, they are now fully and simply partisan. In this political maelstrom, the failure of capand-trade climate policy in the U.S. Senate in 2010 was essentially collateral damage in a much larger political war.

The successful political battle against the Obama administration's $\mathrm{CO}_{2}$ cap-and-trade legislation featured the demonization of that instrument as "cap-and-tax." Does the consequent reputational loss for cap-and-trade present an opening for serious consideration of the other carbon-pricing instrument - a carbon tax? The ongoing challenge of large budgetary deficits may increase the political feasibility of new sources of revenue. When and if that happens, consumption taxes (as opposed to traditional taxes on income and investment) could receive heightened attention, and primary among these might be energy or carbon taxes. 
Surely this opening already exists in the broader policy community, with support not only from the usual Democratic sources, but also from prominent Republican academic economists and former high government officials. The January 16, 2019 economists' statement on a carbon dividend plan in the Wall Street Journal (Akerloff et al. 2019) and support from the Niskanen Center provide evidence of the diversity of bipartisan support for a carbon tax (typically in the form of a carbon dividend plan) in the broader policy community.

What about in the real political world of those currently holding elective office in the Federal government? The good news is that a carbon tax is not "cap-and-trade." That may help with the political messaging. But if conservatives were able to tarnish cap-and-trade as "capand-tax," it surely will not be very difficult to label a tax (or a "fee") - as a tax. In addition to opposition from the right, it is - as of now - questionable whether the new left of the Democratic Party in the Congress will want a carbon tax to be part of its promoted "Green New Deal." So, for the short term, national carbon-pricing of either type may continue to face an uphill battle in the United States.

Therefore, in addition to economic research on judicious design of second-best carbonpricing policies, economists can be effective by working to catch up with the political world by examining better design of second-best non-pricing climate policy instruments, such as clean energy standards. $^{48}$ But at some point the politics will change, and it is important to be ready, which is why - for the long term - ongoing research on carbon-pricing instruments is very much warranted, particularly if it is carried out in the context of real-world politics and focuses on policies that are likely at some point to prove feasible.

\footnotetext{
${ }^{48}$ For example, the “Clean Energy Standard Act of 2019,” Senate Bill 1359, introduced on May 8, 2019, would establish a standard for clean generation of electricity with a market-oriented credit trading program.
} 
Table 1:

Implemented and Scheduled Carbon-Pricing Initiatives, 1990-2020

\begin{tabular}{|c|c|c|c|c|c|c|}
\hline Initiative & Type & Status & $\begin{array}{c}\text { Type of } \\
\text { Jurisdiction }\end{array}$ & Jurisdiction & Year & $\begin{array}{c}\text { GHG } \\
\text { Emissions } \\
\text { [MtCO2e] }\end{array}$ \\
\hline $\begin{array}{l}\text { Alberta Carbon Competitiveness } \\
\text { Incentive Regulation }\end{array}$ & Trading & Implemented & Sub-National & Alberta & 2007 & 120 \\
\hline $\begin{array}{l}\text { Alberta Carbon Tax (repealed, } \\
\text { May 2019) }\end{array}$ & Tax & Implemented & Sub-National & Alberta & 2017 & 109 \\
\hline Argentina Carbon Tax & Tax & Scheduled & National & Argentina & 2019 & 79 \\
\hline $\begin{array}{l}\text { Australia Emissions Reduction } \\
\text { Fund Safeguard Mechanism }\end{array}$ & Trading & Implemented & National & Australia & 2016 & 381 \\
\hline $\begin{array}{l}\text { BC Greenhouse Gas Industrial } \\
\text { Reporting and Control Act }\end{array}$ & Trading & Implemented & Sub-National & $\begin{array}{l}\text { British } \\
\text { Columbia } \\
\end{array}$ & 2016 & 0 \\
\hline BC Carbon Tax & Tax & Implemented & Sub-National & $\begin{array}{l}\text { British } \\
\text { Columbia }\end{array}$ & 2008 & 42 \\
\hline $\begin{array}{l}\text { Beijing } \\
\text { Emissions Trading System }\end{array}$ & Trading & Implemented & Sub-National & Beijing & 2013 & 85 \\
\hline $\begin{array}{l}\text { California AB-32/AB-398 } \\
\text { Cap-and-Trade System }\end{array}$ & Trading & Implemented & Sub-National & California & 2012 & 378 \\
\hline $\begin{array}{l}\text { Canada Federal } \\
\text { Output-Based Pricing System }\end{array}$ & Trading & Scheduled & National & Canada & 2019 & ? \\
\hline Canada Federal Carbon Tax & Tax & Scheduled & National & Canada & 2019 & $?$ \\
\hline Chile Carbon Tax & Tax & Implemented & National & Chile & 2017 & 47 \\
\hline $\begin{array}{l}\text { China National } \\
\text { Emissions Trading System }\end{array}$ & Trading & Scheduled & National & China & 2020 & 3,232 \\
\hline $\begin{array}{l}\text { Chongqing } \\
\text { Emissions Trading System }\end{array}$ & Trading & Implemented & Sub-National & Chongqing & 2014 & 97 \\
\hline Colombia Carbon Tax & Tax & Implemented & National & Colombia & 2017 & 42 \\
\hline Denmark Carbon Tax & $\operatorname{Tax}$ & Implemented & National & Denmark & 1992 & 22 \\
\hline $\begin{array}{l}\text { European Union } \\
\text { Emissions Trading System }\end{array}$ & Trading & Implemented & Regional & $\begin{array}{l}\text { EU plus Nor., } \\
\text { Ice., \& Lich. }\end{array}$ & 2005 & 2,132 \\
\hline Estonia Carbon Tax & Tax & Implemented & National & Estonia & 2000 & 1 \\
\hline Finland Carbon Tax & Tax & Implemented & National & Finland & 1990 & 25 \\
\hline France Carbon Tax & $\operatorname{Tax}$ & Implemented & National & France & 2014 & 176 \\
\hline $\begin{array}{l}\text { Fujian } \\
\text { Emissions Trading System }\end{array}$ & Trading & Implemented & Sub-National & Fujian & 2016 & 200 \\
\hline $\begin{array}{l}\text { Guangdong } \\
\text { Emissions Trading System }\end{array}$ & Trading & Implemented & Sub-National & Guangdong & 2013 & 366 \\
\hline $\begin{array}{l}\text { Hubei } \\
\text { Emissions Trading System }\end{array}$ & Trading & Implemented & Sub-National & Hubei & 2014 & 162 \\
\hline
\end{tabular}


Table 1 (continued)

\begin{tabular}{|c|c|c|c|c|c|c|}
\hline Initiative & Type & Status & $\begin{array}{c}\text { Type of } \\
\text { Jurisdiction }\end{array}$ & Jurisdiction & Year & $\begin{array}{c}\text { GHG } \\
\text { Emissions } \\
\text { [MtCO2e] }\end{array}$ \\
\hline Ireland Carbon Tax & Tax & Implemented & National & Ireland & 2010 & 31 \\
\hline Japan Carbon Tax & Tax & Implemented & National & Japan & 2012 & 999 \\
\hline $\begin{array}{l}\text { Kazakhstan } \\
\text { Emissions Trading System }\end{array}$ & Trading & Implemented & National & Kazakhstan & 2013 & 183 \\
\hline $\begin{array}{l}\text { Korea } \\
\text { Emissions Trading System }\end{array}$ & Trading & Implemented & National & Korea & 2015 & 453 \\
\hline Latvia Carbon Tax & Tax & Implemented & National & Latvia & 2004 & 2 \\
\hline Liechtenstein Carbon Tax & Tax & Implemented & National & Liechtenstein & 2008 & 0 \\
\hline $\begin{array}{l}\text { Massachusetts } \\
\text { Cap-and-Trade System }\end{array}$ & Trading & Implemented & Sub-National & RGGI States & 2018 & 10 \\
\hline Mexico Carbon Tax & Tax & Implemented & National & Mexico & 2014 & 307 \\
\hline $\begin{array}{l}\text { New Zealand } \\
\text { Emissions Trading System }\end{array}$ & Trading & Implemented & National & New Zealand & 2008 & 40 \\
\hline Norway Carbon Tax & Tax & Implemented & National & Norway & 1991 & 40 \\
\hline Poland Carbon Tax & Tax & Implemented & National & Poland & 1990 & 16 \\
\hline Portugal Carbon Tax & Tax & Implemented & National & Portugal & 2015 & 21 \\
\hline $\begin{array}{l}\text { Quebec } \\
\text { Cap-and-Trade System }\end{array}$ & Trading & Implemented & Sub-National & Quebec & 2013 & 67 \\
\hline $\begin{array}{l}\text { Regional Greenhouse Gas } \\
\text { Initiative }\end{array}$ & Trading & Implemented & Sub-National & RGGI States & 2009 & 94 \\
\hline $\begin{array}{l}\text { Saitama } \\
\text { Emissions Trading System }\end{array}$ & Trading & Implemented & Sub-National & Saitama & 2011 & 7 \\
\hline $\begin{array}{l}\text { Shanghai } \\
\text { Emissions Trading System }\end{array}$ & Trading & Implemented & Sub-National & Shanghai & 2013 & 170 \\
\hline $\begin{array}{l}\text { Shenzhen } \\
\text { Emissions Trading System }\end{array}$ & Trading & Implemented & Sub-National & Shenzhen & 2013 & 61 \\
\hline Singapore Carbon Tax & Tax & Scheduled & National & Singapore & 2019 & 42 \\
\hline Slovenia Carbon Tax & Tax & Implemented & National & Slovenia & 1996 & 5 \\
\hline South Africa Carbon Tax & Tax & Scheduled & National & South Africa & 2019 & 360 \\
\hline Spain Carbon Tax & Tax & Implemented & National & Spain & 2014 & 9 \\
\hline Sweden Carbon Tax & Tax & Implemented & National & Sweden & 1991 & 26 \\
\hline $\begin{array}{l}\text { Switzerland } \\
\text { Emissions Trading System }\end{array}$ & Trading & Implemented & National & Switzerland & 2008 & 6 \\
\hline
\end{tabular}


Table 1 (continued)

\begin{tabular}{|c|c|c|c|c|c|c|}
\hline Switzerland Carbon Tax & Tax & Implemented & National & Switzerland & 2008 & 18 \\
\hline $\begin{array}{l}\text { Tianjin } \\
\text { Emissions Trading System }\end{array}$ & Trading & Implemented & Sub-National & Tianjin & 2013 & 118 \\
\hline $\begin{array}{l}\text { Tokyo } \\
\text { Cap-and-Trade System }\end{array}$ & Trading & Implemented & Sub-National & Tokyo & 2010 & 14 \\
\hline UK Carbon Price Floor & Tax & Implemented & National & $\begin{array}{l}\text { United } \\
\text { Kingdom }\end{array}$ & 2013 & 136 \\
\hline Ukraine Carbon Tax & Tax & Implemented & National & Ukraine & 2011 & 287 \\
\hline $\begin{array}{l}\text { Washington State } \\
\text { Clean Air Rule }\end{array}$ & Trading & Implemented & Sub-National & Washington & 2017 & 58 \\
\hline
\end{tabular}

SOURCE: World Bank Group. 2018. State and Trends of Carbon Pricing. Washington, D.C. 
Table 2:

Similarities and Differences

Between Carbon Taxes and Carbon Cap-and-Trade

\begin{tabular}{|c|c|c|c|c|c|}
\hline $\begin{array}{c}\text { Perfectly } \\
\text { Equivalent }\end{array}$ & $\begin{array}{c}\text { Nearly } \\
\text { Equivalent }\end{array}$ & Similar & $\begin{array}{c}\text { Some } \\
\text { Distinctions }\end{array}$ & Differences & $\begin{array}{l}\text { Significant } \\
\text { Differences }\end{array}$ \\
\hline \multicolumn{6}{|l|}{$\begin{array}{l}\text { Incentives for } \\
\text { Emission } \\
\text { Reductions }\end{array}$} \\
\hline \multicolumn{6}{|l|}{$\begin{array}{c}\text { Aggregate } \\
\text { Abatement Costs }\end{array}$} \\
\hline \multicolumn{6}{|l|}{$\begin{array}{c}\text { Effects on } \\
\text { Competitiveness }\end{array}$} \\
\hline & $\begin{array}{l}\text { Possibilities for } \\
\text { Raising Revenue }\end{array}$ & & & & \\
\hline & & $\begin{array}{c}\text { Costs to } \\
\text { Regulated Firms }\end{array}$ & & & \\
\hline & & $\begin{array}{l}\text { Distributional } \\
\text { Impacts }\end{array}$ & & & \\
\hline & & & $\begin{array}{c}\text { Transaction } \\
\text { Costs }\end{array}$ & & \\
\hline & & & & $\begin{array}{l}\text { Performance in } \\
\text { Presence of } \\
\text { Uncertainty }\end{array}$ & \\
\hline & & & & $\begin{array}{c}\text { Ease of Linkage } \\
\text { with Other } \\
\text { Jurisdictions }\end{array}$ & \\
\hline & & & & & $\begin{array}{c}\text { Effects on } \\
\text { Carbon Price } \\
\text { Volatility }\end{array}$ \\
\hline & & & & & $\begin{array}{c}\text { Interactions with } \\
\text { Complementary } \\
\text { Policies }\end{array}$ \\
\hline & & & & & $\begin{array}{c}\text { Potential for } \\
\text { Market } \\
\text { Manipulation }\end{array}$ \\
\hline & & & & & $\begin{array}{l}\text { Complexity and } \\
\text { Administrative } \\
\text { Requirements }\end{array}$ \\
\hline
\end{tabular}


Table 3:

Most Important Cap-and-Trade Systems

\begin{tabular}{|c|c|c|c|c|c|c|}
\hline System & $\begin{array}{l}\text { Geographic } \\
\text { Scope }\end{array}$ & $\begin{array}{c}\text { Coverage } \\
\& \\
\text { Sectors }\end{array}$ & $\begin{array}{l}\text { Time } \\
\text { Period }\end{array}$ & $\begin{array}{c}\text { Allowance } \\
\text { Allocation } \\
\text { Method }\end{array}$ & \begin{tabular}{l}
\multicolumn{1}{c}{ Cost } \\
Containment \\
Mechanisms
\end{tabular} & $\begin{array}{c}\text { Environmental } \\
\text { and } \\
\text { Economic Performance }\end{array}$ \\
\hline $\begin{array}{l}\text { Leaded Gasoline } \\
\text { Phasedown }\end{array}$ & USA & $\begin{array}{l}\text { Gasoline } \\
\text { from } \\
\text { Refineries }\end{array}$ & 1982-1987 & Free & Banking & $\begin{array}{l}\text { Phasedown completed } \\
\text { successfully, faster than } \\
\text { anticipated, with cost savings of } \\
20 \% \text { or } \$ 250 \text { million/year }\end{array}$ \\
\hline $\begin{array}{l}\text { Sulfur Dioxide } \\
\text { Allowance Trading }\end{array}$ & USA & $\begin{array}{l}\mathrm{SO}_{2} \text { from } \\
\text { Electric } \\
\text { Power }\end{array}$ & $1995-2010$ & Free & Banking & $\begin{array}{l}\text { Cut } \mathrm{SO}_{2} \text { emissions by half, with } \\
\text { cost savings of } \$ 1 \text { billion/year; } \\
\text { but market closed due to judicial } \\
\text { actions }\end{array}$ \\
\hline $\begin{array}{l}\text { Regional Clean Air } \\
\text { Incentives Market } \\
\text { (RECLAIM) }\end{array}$ & $\begin{array}{l}\text { South Coast } \\
\text { Air Quality } \\
\text { Management } \\
\text { District, CA }\end{array}$ & $\begin{array}{l}\mathrm{NO}_{\mathrm{x}} \& \\
\mathrm{SO}_{2} \text { from } \\
\text { Electric } \\
\text { Power \& } \\
\text { Industrial } \\
\text { Sources }\end{array}$ & $\begin{array}{c}\text { 1993- } \\
\text { present }\end{array}$ & Free & --- & $\begin{array}{l}\text { Emissions lower than with } \\
\text { parallel regulations; un- } \\
\text { quantified cost savings; } \\
\text { electricity crisis caused } \\
\text { allowance price spike and } \\
\text { temporary suspension of market }\end{array}$ \\
\hline $\begin{array}{l}\mathrm{NO}_{\mathrm{X}} \text { Trading in the } \\
\text { Eastern United States }\end{array}$ & $\begin{array}{c}12-21 \\
\text { U.S. States }\end{array}$ & $\begin{array}{l}\mathrm{NO}_{\mathrm{x}} \text { from } \\
\text { Electric } \\
\text { Power \& } \\
\text { Industrial } \\
\text { Sources }\end{array}$ & $1999-2008$ & Free & --- & $\begin{array}{l}\text { Significant price volatility in } \\
\text { first year; } \mathrm{NO}_{\mathrm{x}} \text { emissions } \\
\text { declined from } 1.9(1990) \text { to } 0.5 \\
\text { million tons (2006); cost savings } \\
40-47 \text { percent }\end{array}$ \\
\hline $\begin{array}{l}\text { Regional Greenhouse } \\
\text { Gas Initiative }\end{array}$ & $\begin{array}{l}\text { Nine } \\
\text { northeastern } \\
\text { U.S. States }\end{array}$ & $\begin{array}{l}\mathrm{CO}_{2} \text { from } \\
\text { Electric } \\
\text { Power }\end{array}$ & $\begin{array}{l}\text { 2009- } \\
\text { present }\end{array}$ & $\begin{array}{l}\text { Nearly } \\
100 \% \\
\text { Auction }\end{array}$ & $\begin{array}{c}\text { Banking, Cost } \\
\text { Containment } \\
\text { Reserve, Auction } \\
\text { Reservation Price }\end{array}$ & $\begin{array}{l}\text { Cap non-binding then barely } \\
\text { binding due to low natural gas } \\
\text { prices; has generated more than } \\
\$ 1 \text { billion for participating states }\end{array}$ \\
\hline $\begin{array}{l}\text { AB-32 and AB-398 } \\
\text { California Cap-and- } \\
\text { Trade }\end{array}$ & $\begin{array}{c}\text { California, } \\
\text { USA }\end{array}$ & $\begin{array}{l}\mathrm{CO}_{2} \text { from } \\
\text { Electric } \\
\text { Power, } \\
\text { Industrial, } \\
\text { \& Fuels }\end{array}$ & $\begin{array}{l}2013-2020 \\
2021-2030\end{array}$ & $\begin{array}{l}\text { Transitions } \\
\text { from Free } \\
\text { to Auction }\end{array}$ & $\begin{array}{c}\text { Banking, } \\
\text { Allowance Price } \\
\text { Containment } \\
\text { Reserve, Auction } \\
\text { Reservation Price }\end{array}$ & $\begin{array}{l}\text { Covers } 85 \% \text { of emissions, } \\
\text { reduced } 40 \% \text { below } 1990 \text { by } \\
2030 \text {; reduces competitiveness } \\
\text { effects w/output-based updating } \\
\text { (OBU) allocation; linked with } \\
\text { Quebec cap-and-trade system }\end{array}$ \\
\hline $\begin{array}{l}\text { European Union } \\
\text { Emissions Trading } \\
\text { System }\end{array}$ & $\begin{array}{l}27 \text { EU } \\
\text { Member } \\
\text { States plus } \\
\text { Iceland, } \\
\text { Lichtenstein, } \\
\text { \& Norway }\end{array}$ & $\begin{array}{l}\mathrm{CO}_{2} \text { from } \\
\text { Electric } \\
\text { Power, } \\
\text { Large } \\
\text { Industrial, } \\
\text { \& Aviation }\end{array}$ & 2005- & $\begin{array}{l}\text { Transitions } \\
\text { from Free } \\
\text { to } \\
\text { Increased } \\
\text { Use of } \\
\text { Auctions }\end{array}$ & $\begin{array}{l}\text { Banking after } \\
\text { 2008, previous } \\
\text { use of offsets } \\
\text { from CDM }\end{array}$ & $\begin{array}{l}\text { Covers half of emissions, has } \\
\text { cut abatement costs by about } \\
50 \% \text { compared with no trading; } \\
\text { over-allocation by member } \\
\text { states in pilot phase; suppressed } \\
\text { allowance prices due to } \\
\text { "complementary policies," } \\
\text { CDM glut, slow economic } \\
\text { recovery }\end{array}$ \\
\hline
\end{tabular}

SOURCE: Table is adapted from Schmalensee and Stavins 2017a. Sources include: Carlson et al. 2000; Cludius et al. 2019; Ellerman et al. 2000; Ellerman and Buchner 2007; Fowlie et al. 2012; Keohane 2003; Schmalensee and Stavins 2013, 2017a, 2017b; and U.S. Environmental Protection Agency 1985. 
Figure 1:

Carbon Price and Emissions Coverage of Implemented Carbon-Pricing Initiatives

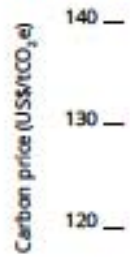

110

Liechtenstein carbon tax

Switzerland carbon tax

Finland carbon tax

France carbon tax

100 - Uikraine carbon tax

Iceland carbon tax.

Poland carbon tax

Denmark carbon tax

BC carbon tax

90- Givargdong pillot ETS

K carbon price floor

Ireland carbon taxy

Spain carbon taxil

Aberta carbon tax i i

80_- Estonia carbon tax

uifian piloe EIS

$70-1$

(1)

Colombia carbon tax

60-1

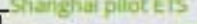

${ }_{40}^{50-1} \quad$ S

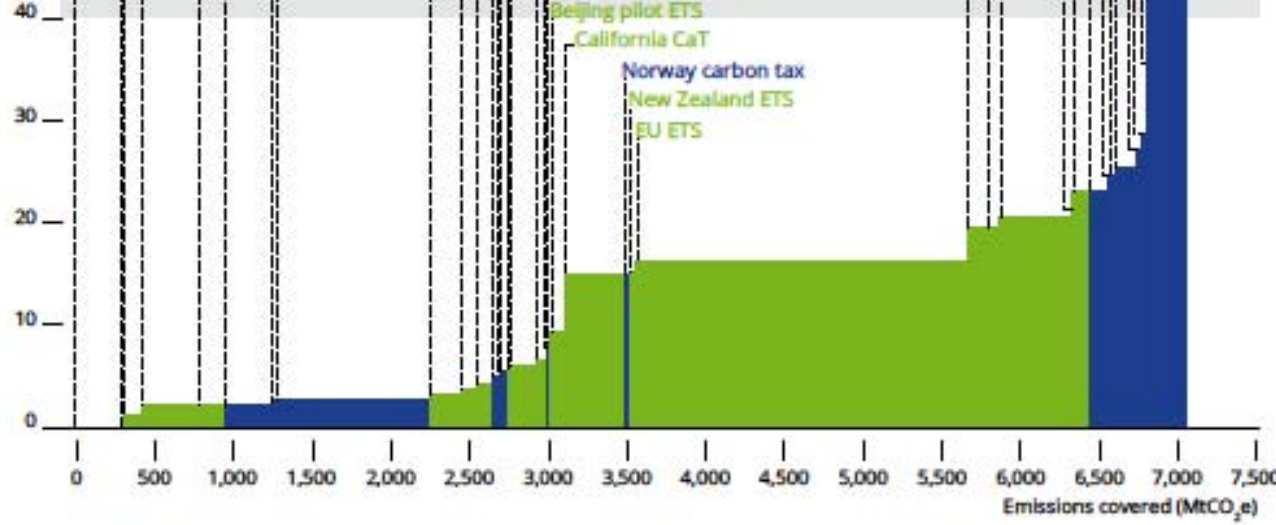

Carbon price range needed in 2020 to stay consstert with achieving the temperature gos

of the Paris Agreement as identified by the High Level Commission on Carbon Prices

ETS

Carbon $\operatorname{tax}$

Note The Australla EFF Safeguard Mecharism, Betikh Columbia GGIRCA. Kazaihstan ETS and Washington CAR are not shown in this graph as price information is not

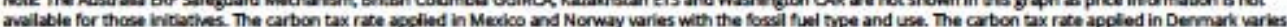
with the GHG type. The graph shows the awerage carbon tax rate weigtted by the amount of emissions covered at the different tax rates in these jurisdictions.

SOURCE: World Bank Group 2018 


\section{REFERENCES}

Akerloff, George et al. 2019. “Economists’ Statement on Carbon Dividends.” Opinion/Commentary. Wall Street Journal, January 16.

Aldy, Joseph E. 2018. “Carbon Tax Review and Updating.” Unpublished paper, John F. Kennedy School of Government, Harvard University, Cambridge.

Aldy, Joseph E., Marc Hafstead, Gilbert E. Metcalf, Brian C. Murray, William A. Pizer, Christina Reichert, and Roberton W. Williams. 2017. "Resolving Inherent Uncertainty of Carbon Taxes.” Harvard Environmental Law Review, volume 41, pp. 1-13.

Aldy, Joseph E., and Robert N. Stavins. 2012. “The Promise and Problems of Pricing Carbon: Theory and Practice.” Journal of Environment and Development 21(2): 152-180.

Amdur David, Barry G. Rabe, and Christopher Borick. 2014. "Public Views on a Carbon Tax Depend on the Proposed Use of Revenue.” Issues in Energy and Environmental Policy, Number 13, July.

Anderson, Soren, Ioana Marinescu, and Boris Shor. 2018. "Who Joined the Pigou Club? A Postmortem Analysis of Washington State’s Carbon Tax Initiative I-732.” June 6.

Arrow, Kennth J. 1969. "The Organization of Economic Activity: Issues Pertinent to the Choice of Market versus Non-Market Allocation.” Congress of the United States, The Analysis and Evaluation of Public Expenditures: The PPB System, pp. 47-64.

Beck, Marisa, Nicholas Rivers, Randall Wigle, and Hidemichi Yonezawa. 2015. "Carbon Tax and Revenue Recycling: Impacts on Households in British Columbia.” Resource and Energy Economics 41: 40-69.

Becker, Gary S. 1983. “A Theory of Competition among Pressure Groups for Political Influence.” Quarterly Journal of Economics 98(3):371-400.

Bodansky, Daniel, Seth Hoedl, Gilbert Metcalf, and Robert Stavins. 2015. "Facilitating Linkage of Climate Policies through the Paris Outcome.” Climate Policy, August 5.

Boden, T.A., Marland, G., and Andres, R.J. 2017. National CO2 Emissions from Fossil-Fuel Burning, Cement Manufacture, and Gas Flaring: 1751-2014. Carbon Dioxide Information Analysis Center, Oak Ridge National Laboratory, U.S. Department of Energy.

Bohi, Douglas and Dallas Burtraw. 1992. "Utility Investment Behavior and the Emission Trading Market." Resources and Energy 14: 129-153.

Borenstein, Severin, James Bushnell, Frank A. Wolak, and Matthew Zaragoza-Watkins. 2018 "Expecting the Unexpected: Emissions Uncertainty and Environmental Market Design.” Energy Institute at Haas Working Paper 274R. June.

Bovenberg, A. Lans, and Lawrence H. Goulder. 1996. "Optimal Environmental Taxation in the Presence of Other Taxes: General Equilibrium Analyses.” American Economic Review 86: 985-1000.

Boyce, James K., and Matthew Riddle. 2007. "Cap and Dividend: How to Cap Global Warming while Protecting the Incomes of American Families.” Amherst: University of Massachusetts. 
Burtraw, Dallas, Richard Morgenstern, Amelia Keyes, and Clayton Munnings. 2019. "Carbon Pricing in Oregon: Memoranda for the Oregon Climate Policy Office. Washington, January, Report 19-01.

British Columbia. 2007. Climate Action Plan. Vancouver, Canada.

Bruvoll, Annegrete and Bodil Merethe Larsen. 2004. "Greenhouse Gas Emissions in Norway: Do Carbon Taxes Work?” Energy Policy 32: 493-505.

Buchanan, James M., and Gordon Tullock. 1975. "Polluters' Profits and Political Response: Direct Control Versus Taxes.” American Economic Review 65: 139-147.

Calel, R. and Dechezlepretre, A. 2016. "Environmental policy and directed technological change: Evidence from the European carbon market.” Review of Economics and Statistics 98(1): 173-191.

Carl, Jeremy, and David Fedor. 2016. “Tracking Global Carbon Revenues: A Survey of Carbon Taxes versus Cap-and-Trade in the Real World.” Energy Policy 96: 50-77.

Carlson, Curtis, Dallas Burtraw, Maureen Cropper, and Karen Palmer. 2000. $\mathrm{SO}_{2}$ Control by Electric Utilities: What Are the Gains from Trade? Journal of Political Economy 108: 1292-326.

Carattini, Stefano, Maria Carvalho, and Sam Fankhauser. 2017. "How to Make Carbon Taxes More Acceptable.” London: Grantham Research Institute on Climate Change and the Environment, and Centre for Climate Change Economics and Policy, London School of Economics and Political Science.

Chen, Yunguang, and Marc A. C. Hafstead. 2018. "Using a Carbon Tax to Meet U.S. International Climate Pledges.” Climate Change Economics 10(1): 195002-1 - 195002-19.

Climate XChange. 2019. “Cap-and-Trade Could be Coming to Oregon - Here's What You Need to Know.” Carbon Pulse, February 8.

Cludius, Johanna, Vicky Duscha, Nele Friedrichsen, and Katja Schumacher. 2019 "Cost-Efficiency of the EU Emissions Trading System: An Evaluation of the Second Trading Period.” Economics of Energy and Environmental Policy 8(1): 145-161.

Coase, Ronald. 1960. "The Problem of Social Cost." Journal of Law and Economics 3: 1-44.

Crocker, Thomas D. 1966. "The Structuring of Atmospheric Pollution Control Systems." In The Economics of Air Pollution, ed.. H. Wolozin, pp. 61-86. New York: W. W. Norton and Company, Inc.

Dales, J. H. 1968. "Land, Water, Ownership.” Canadian Journal of Economics 1: 791-804.

Datla, Anjani and Henry Lee. 2016. "Pricing Carbon: The Birth of British Columbia’s Carbon Tax.” Harvard Kennedy School Case Number 2062.0.

Daugjberg, Cartsen and Anders Branth Pedersen. 2004. "New Policy Ideas and Old Policy Networks: Implementing Green Taxation in Scandinavia.” Journal of Public Policy 24(2): 219-249.

Doucet, Joseph A., and Todd Strauss. 1994. On the Bundling of Coal and Sulfur Dioxide Emissions Allowances. Energy Policy, Volume 22, Number 9, pp. 764-770. 
Driesen, David. M. 2019. "Toward a Populist Political Economy of Climate Disruption.” Environmental Law, volume 49, number 2, forthcoming.

Duff, David G. 2008. “Carbon Taxation in British Columbia.” Vermont Journal of Environmental Law 10: 85-105.

Edenhofer, Ottmar, Christian Flachsland, Christoph, Lisa Katharina Schmid, Anna Leipprand, Nicolas Koch, Ulrike Kornek, and Michael Pahle. 2017. "Decarbonization and EU ETS Reform: Introducing a Price Floor to Drive Low-Carbon Investments.” Berlin: Mercator Research Instituteon Global Commons and Climate Change.

Ellerman, A. Denny, and Barbara K. Buchner. 2007. The European Union Emissions Trading Scheme: Origins, Allocation, and Early Results. Review of Environmental Economics and Policy, volume 1, number 1, pp. 66-87.

Ellerman, A. Denny, Frank J. Convery, and Christian de Perthuis, eds. 2010. Pricing Carbon: The European Union Emissions Trading Scheme. Cambridge, United Kingdom: Cambridge University Press.

Ellerman, A. Denny, Paul L. Joskow, and David Harrison. 2003. Emissions Trading in the U.S.: Experience, Lessons, and Considerations for Greenhouse Gases. Arlington, Virginia: Pew Center on Global Climate Change.

Ellerman, A. Denny, Paul L. Joskow, Richard Schmalensee, Juan-Pablo Montero, and Elizabeth M. Bailey. 2000. Markets for Clean Air: The U.S. Acid Rain Program. Cambridge, UK: Cambridge University Press.

Ellerman, A. Denny, and Juan-Pablo Montero. 1998. "The Declining Trend in Sulfur Dioxide Emissions: Implications for Allowance Prices", Journal of Environmental Economics and Management 36:2645.

Fankhauser, Samuel, Cameron Hepburn, and Jisung Park. 2010. “Combining Multiple Climate Policy Instruments: How Not to Do It.” Climate Change Economics 1(3): 209-225.

Fischer, Carolyn, Ian W. H. Parry, and William A. Pizer. 2003. "Instrument Choice for Environmental Protection when Technological Innovation is Endogenous." Journal of Environmental Economics and Management 45: 523-545.

Fowlie, Meredith, Stephen P. Holland, and Erin T. Mansur. 2012. "What Do Emissions Markets Deliver and to Whom? Evidence from Southern California’s NOx Trading Program.” American Economic Review, Vol. 102, No. 2 (April), pp. 965-993.

Fowlie, Meredith, Mar Reguant, and Stephen P. Ryan. 2016. "Market-Based Emissions Regulation and Industry Dynamics.” Journal of Political Economy 124(1): 249-302.

Furman, Jason, Jason E. Bordoff, Manasi Deshpande, and Pascal J. Noel. 2007. "An Economic Strategy to Address Climate Change and Promote Energy Security." The Hamilton Project, Strategy Paper. Washington, D.C.: The Brookings Institution.

Gillis, Justin. 2018. “Forget the Carbon Tax for Now.” New York Times, December 27.

Government Offices of Sweden. 2019. “Sweden’s Carbon Tax.” Accessed, January 25, https://www.government.se/government-policy/taxes-and-tariffs/swedens-carbon-tax/ 
Goulder, Lawrence H. 1995. “Environmental Taxation and the 'Double Dividend': A Reader's Guide.” International Tax and Public Finance 2(2).

Goulder, Lawrence H. 2019a. Presentation at Winter Luncheon and Annual Business Meeting, Association of Environmental and Resource Economists, Atlanta, Georgia, January 5.

Goulder, Lawrence H. 2019b. “Addressing the Urgency of Climate-Change Policy.” Working paper, Stanford University, March.

Goulder, Lawrence H., and Mark A. C. Hafstead. 2018. Confronting the Climate Challenge: U.S. Policy Options. New York: Columbia University Press.

Goulder, Lawrence H., Marc A. C. Hafstead, GyuRim Kim, and Xianling Long. 2018. "Impacts of a Carbon Tax across U.S. Household Income Groups: What are the Equity-Efficiency Trade-Offs?” National Bureau of Economic Research Working Paper No. 25181, October.

Goulder, Lawrence H., and Richard D. Morgenstern. 2018. “China’s Rate-Based Approach to Reducing $\mathrm{CO}_{2}$ Emissions: Attractions, Limitations, and Alternatives.” American Economic Review Papers and Proceedings 108: 458-462.

Goulder, Lawrence H., and Andrew R. Schein. 2013. "Carbon Taxes versus Cap and Trade: A Critical Review.” Climate Change Economics 4(3).

Goulder, Lawrence H., and Robert N. Stavins. 2011. "Challenges from State-Federal Interactions in U.S. Climate Change Policy." American Economic Review Papers and Proceedings, volume 101, number 3, pp. 253-257.

Hafstead, Marc, Gilbert E. Metcalf, and Roberton C. Williams. 2017. “Adding Quantity Certainty to a Carbon Tax: The Role of a Tax Adjustment Mechanism for Policy Pre-Commitment." Harvard Environmental Law Review, volume 41, pp. 41-57.

Hahn, Robert W. 1984. "Market Power and Transferable Property Rights." Quarterly Journal of Economics 99: 753-765.

Hahn, Robert W. and Albert M. McGartland. 1989. "The Political Economy of Instrument Choice: an Examination of the U.S. Role in Implementing the Montreal Protocol." Northwestern University Law Review 83(3): 592-611.

Hahn, Robert W., and Robert N. Stavins. 1992. "Economic Incentives for Environmental Protection: Integrating Theory and Practice.” American Economic Review Papers and Proceedings 82: 464468.

Hahn, Robert W., and Robert N. Stavins. 1999. What Has the Kyoto Protocol Wrought? The Real Architecture of International Tradeable Permit Markets. Washington, D.C.: The AEI Press.

Hahn, Robert W., and Robert N. Stavins. 2012. "The Effect of Allowance Allocations on Cap-and-Trade System Performance.” The Journal of Law and Economics 54(4), pp. S267-S294.

Harder, Amy. 2019. “In Shadow of Green New Deal, Other Climate-Change Bills Proliferate.” Axios, April 10.

Harrison, Kathryn. 2013. “The Political Economy of British Columbia's Carbon Tax.” OECD Environment Working Paper No. 63. OECD Publishing. 
Hoel, Michael, and Larry Karp. 2001. "Taxes and Quotas for a Stock Pollutant with Multiplicative Uncertainty.” Journal of Public Economics 82: 91-114.

Hoel, Michael, and Larry Karp. 2002. “Taxes versus Quotas for a Stock Pollutant.” Resource and Energy Economics 24: 367-384.

Holt, C. A., and Shobe, W.M. 2016. "Price and Quantity Collars for Stabilizing Emission Allowance Prices: Laboratory Experiments on the EU ETS Market Stability Reserve”, Journal of Environmental Economics and Management, 76, 32-50.

Interagency Working Group on Social Cost of Carbon. 2016. "United States Government Update of the Social Cost of Carbon for Regulatory Impact Analysis under Executive Order 12866.” Washington.

Intergovernmental Panel on Climate Change. 2013. Climate Change 2013: The Physical Science Basis. Cambridge, U.K.: Cambridge University Press.

Intergovernmental Panel on Climate Change. 2018. Global Warming of $1.5^{\circ}$ C, IPCC Special Report, Summary for Policymakers. World Meteorological Organization and United Nations Environment Program.

Jaffe, Adam B., Richard G. Newell, and Robert N. Stavins. 2005. "Tale of Two Market Failures: Technology and Environmental Policy.” Ecological Economics 54: 164174.

Jaffe, Adam B., and Robert N. Stavins. 1995. "Dynamic Incentives of Environmental Regulation: The Effects of Alternative Policy Instruments on Technology Diffusion." Journal of Environmental Economics and Management 29: S43-S63.

Jaffe, Judson, Matthew Ranson, and Robert N. Stavins. 2010. "Linking Tradable Permit Systems: A Key Element of Emerging International Climate Policy Architecture." Ecology Law Quarterly 36: 789-808.

Joskow, Paul L., and Richard Schmalensee. 1998. "The Political Economy of Market-based Environmental Policy: The U.S. Acid Rain Program.” Journal of Law and Economics 41:81-135.

Jung, Chulho, Kerry Krutilla, and Roy Boyd. 1996. "Incentives for Advanced Pollution Abatement Technology at the Industry Level: An Evaluation of Policy Instruments." Journal of Environmental Economics and Management 30: 95-111.

Kagubare, Ines. 2019. “Legislators Roll Out Climate Bills as Session Opens.” Climate Wire, January 15.

Kalt, Joseph P. and Mark A. Zupan. 1984. "Capture and Ideology in the Economic Theory of Politics.” American Economic Review 74(3):279-300.

Kaplow, Louis. 2010. "Taxes, Permits, and Climate Change." National Bureau of Economic Research Working Paper No. 16268.

Karp, Larry, and Christian Traeger. 2018. "Prices versus Quantities Reassessed.” CESifo Working Paper 7331. Munich Society for the Promotion of Economic Research, November.

Kelman, Steven P. 1981. What Price Incentives? Boston: Auburn House. 
Keohane, Nathaniel O. 2003. "What Did the Market Buy? Cost Savings under the U.S. Tradeable Permits Program for Sulfur Dioxide.” Working Paper YCELP-01-11-2003, Yale Center for Environmental Law and Policy.

Keohane, Nathaniel O. 2009. "Cap and Trade, Rehabilitated: Using Tradable Permits to Control U.S. Greenhouse Gases.” Review of Environmental Economics and Policy 3: 42-62.

Keohane, Nathaniel O., Richard L. Revesz, and Robert N. Stavins. 1998. "The Choice of Regulatory Instruments in Environmental Policy.” Harvard Environmental Law Review, volume 22, number 2, pp. 313-367.

Klaassen, Ger. 1999. Emissions trading in the European Union: practice and prospects. In S. Sorrell and J. Skea Eds., Pollution for Sale: Emissions Trading and Joint Implementation pp. 83-100. Cheltenham, UK: Edward Elgar Publishing.

Kneese, Allen V. and Charles L. Schultze. 1975. Pollution, Prices, and Public Policy. Washington: Brookings Institution.

Kotchen, Matthew J., Zachary M. Turk, and Anthony A. Leiserowitz. 2017. "Public Willingness to Pay for a U.S. Carbon Tax and Preferences for Spending the Revenue.” Environmental Research Letters, volume 12.

Leonhardt, David. 2019. “The Problem with Putting a Price on the End of the World.” New York Times Magazine, April 9.

Lithgow, Matt. 2019a. “Washington State Senator Circulates WCI-Modelled Cap-and-Trade Outline.” Carbon Pulse, January 17.

Lithgow, Matt. 2019b. "Maine Legislator Proposes State-wide Carbon Tax without RGGI Exemption.” Carbon Pulse, January 25.

Lithgow, Matt. 2019c. “New Mexico Governor Calls for Market-Based Programme in Climate Order.” Carbon Pulse, January 29.

Lithgow, Matt. 2019d. “New Hampshire Legislators Propose \$20 Carbon Tax Bill.” Carbon Pulse, January 30.

Lithgow, Matt. 2019e. “Renewed Oregon Cap-and-Trade Push Underway as Bill Released.” Carbon Pulse, February 1.

Lithgow, Matt. 2019f. “LCFS Market: California Prices Near Return to \$200 as PG\&E Fears Pass.” Carbon Pulse, February 8.

Maloney, Michael T., and Robert E. McCormick. 1982. “A Positive Theory of Environmental Quality Regulation.” Journal of Law and Economics 25: 99-123.

Malueg, David A. 1990. "Welfare Consequences of Emission Credit Trading Programs." Journal of Environmental Economics and Management 18: 66-77.

Mankiw, L. Gregory. 2006. "The Pigou Club Manifesto." Greg Mankiw's Blog. http://gregmankiw.blogspot.com/2006/10/pigou-club-manifesto.html 
McCubbins, Matthew and Terry Sullivan. 1984. "Constituency Influences on Legislative Policy Choice.” Quality and Quantity 18:299-319.

McGraw, Dan. 2019. “U.S. Jurisdictions Working on TCI Carbon Pricing Game Plan.” Carbon Pulse, February 8.

Mehling, Michael A., Gilbert E. Metcalf, and Robert N. Stavins. 2018. "Linking Climate Policies to Advance Global Mitigation.” Science 359 (6379), March 2, pp. 997-998.

Metcalf, Gilbert E. 2007. A Proposal for a U.S. Carbon Tax Swap: An Equitable Tax Reform to Address Global Climate Change. The Hamilton Project, Discussion Paper 2007-12. Washington, D.C.: The Brookings Institution.

Metcalf, Gilbert E. 2009. "Market-Based Policy Options to Control U.S. Greenhouse Gas Emissions." Journal of Economic Perspectives 23 (2): 5-27.

Metcalf, Gilbert E. 2018. “The Distributional Impacts of U.S. Energy Policy.” Energy Policy, forthcoming.

Metcalf, Gilbert E. 2019. Paying for Pollution: Why a Carbon Tax is Good for America. New York: Oxford University Press, 2019.

Metcalf, Gilbert E., and David Weisbach. 2012. "Linking Policies When Tastes Differ: Global Climate Policy in a Heterogeneous World.” Review of Environmental Economics and Policy 6(1): 110-129.

Milliman, Scott R., and Raymond Prince. 1989. "Firm Incentives to Promote Technological Change in Pollution Control." Journal of Environmental Economics and Management 17: 247-265.

Mills, Sarah B., Barry G. Rabe, and Christopher Borick. 2015. "Cap-and-Trade Support Linked to Revenue Use.” Issues in Energy and Environmental Policy, Number 23, June.

Montero, Juan-Pablo. 2007. "Tradable Permits with Incomplete Monitoring: Evidence from Santiago's Particulate Permits Program." In Moving to Markets in Environmental Regulation: Lessons from Twenty Years of Experience, eds. J. Freeman and C. Kolstad, pp. 147-170. New York: Oxford University Press.

Montgomery, David W. 1972. "Markets in Licenses and Efficient Pollution Control Programs." Journal of Economic Theory 5: 395-418.

Murray, Brian, William A. Pizer, and Christina Reichert. 2017. "Increasing Emissions Certainty Under a Carbon Tax.” Harvard Environmental Law Review volume 41, pp. 14-27.

Murray, Brian, and Nicholas Rivers. 2015. "British Columbia's Revenue-Neutral Carbon Tax: A Review of the Latest 'Grand Experiment’ in Environmental Policy.” Energy Policy 86: 674-683.

Newell, Richard G., Adam B. Jaffe, and Robert N. Stavins. 1999. "The Induced Innovation Hypothesis and Energy-Saving Technological Change." Quarterly Journal of Economics 114: 941-975.

Newell, Richard G., and William A. Pizer. 2003. "Regulating Stock Externalities Under Uncertainty." Journal of Environmental Economics and Management 45: 416-432.

Newell, Richard G., and Robert N. Stavins. 2003. "Cost Heterogeneity and the Potential Savings from Market-Based Policies.” Journal of Regulatory Economics 23: 43-59. 
Nordhaus, William D. 2007. "To Tax or Not to Tax: Alternative Approaches to Slowing Global Warming." Review of Environmental Economics and Policy 1: 26-44.

Nordhaus, William. 2015. The Climate Casino: Risk, Uncertainty, and Economics for a Warming World. New Haven: Yale University Press.

Organization for Economic Cooperation and Development. 2001. Environmentally Related Taxes in OECD Countries: Issues and Strategies. OECD, Paris.

Organization for Economic Cooperation and Development. 2011. Interactions Between Emission Trading Systems and Other Overlapping Policy Instruments. Environment Directorate, OECD, Paris.

Parry, Ian W. H., and Roberton C. Williams. 2010. "What are the Costs of Meeting Distributional Objectives for Climate Policy?” B.E. Journal of Economic Analysis and Policy 10(2): 1-35.

Parry, Ian W. H., Roberton C. Williams, and Lawrence H. Goulder. 1999. "When Can Carbon Abatement Policies Increase Welfare? The Fundamental Role of Distorted Factor Markets.” Journal of Environmental Economics and Management 37: 52-84.

Paterson, Matthew. 2011. "Who and What are Carbon Markets for? Politics and the Development of Climate Policy.” Climate Policy 11: 1-16.

Peltzman, Sam. 1976. “Toward a More General Theory of Regulation.” Journal of Law and Economics 19:211-240.

Perino, Grischa. 2018. "New EU ETS Phase 4 Rules Temporarily Puncture Waterbed.” Nature Climate Change 8(4): 262-264.

Perino, Grischa, Robert A. Ritz, and Aruthur van Benthem. 2019. "Understanding Overlapping Policies: Internal Carbon Leakage and the Punctured Waterbed.” NBER Working Paper 25643, March. Cambridge, Massachusetts: National Bureau of Economic Research.

Pigou, Arthur C. 1920. The Economics of Welfare. London: Macmillan.

Pindyck, Robert S. 2017. “Coase Lecture - Taxes, Targets, and the Social Cost of Carbon.” Economica 84: 345-364.

Pizer, William A., and Brian C. Prest. 2019. "Prices versus Quantities with Policy Updating.” NBER Working Paper 22379 (2016). National Bureau of Economic Research, June. (Revised, January 6, 2019).

Pizer, William A., and Xiliang Zhang. 2018. “China’s New National Carbon Market.” American Economic Review Papers and Proceedings 108: 463-467.

Plumer, Bradford. 2010. “B.C.'s Carbon-Tax Experiment Seems To Be Working.” The New Republic, July 27.

Pretis, Felix. 2019. "Does a Carbon Tax Reduce $\mathrm{CO}_{2}$ Emissions? Evidence from British Columbia.” February 8. Available at SSRN: https://ssm.com/abstract=3329512

Reklev, Stian. 2019. “China Aims for 2020 ETS Start, Quick Expansion - Sources Citing Govt Plan.” Carbon Pulse, April 12. 
Roberts, Marc J., and Michael Spence. 1976. "Effluent Charges and Licenses Under Uncertainty." Journal of Public Economics 5: 193-208.

Rozenberg, Julie, Adrien Vogt-Schilb, and Stephane Hallegatte. 2019. "Instrument Choice and Stranded Assets in the Transition to Clean Capital.” Journal of Environmental Economics and Management, forthcoming.

Sachs, Jeffrey D. 2018. “For Climate Safety, Call in the Engineers.” Project Syndicate. December 20.

Schatzki, Todd, and Robert N. Stavins. 2018a. "GHG Cap-and-Trade: Implications for Effective and Efficient Climate Policy in Oregon.” Harvard Project on Climate Agreements Discussion Paper 1892, November.

Schatzki, Todd, and Robert N. Stavins. 2018b. “Key Issues Facing California’s GHG Cap-and-Trade System for 2021-2030.” Discussion Paper, July.

Schmalensee, Richard, and Robert N. Stavins. 2013. "The $\mathrm{SO}_{2}$ Allowance Trading System: The Ironic History of a Grand Policy Experiment.” Journal of Economic Perspectives, Volume 27, Number 1, Winter, pp. 103-122.

Schmalensee, Richard, and Robert N. Stavins. 2017a. "Lessons Learned from Three Decades of Experience with Cap and Trade.” Review of Environmental Economics and Policy, Volume 11, Number 1, Summer, pp. 59-79.

Schmalensee, Richard, and Robert N. Stavins. 2017b. “The Design of Environmental Markets: What Have We Learned From Experience With Cap and Trade?” Oxford Review of Economic Policy 33(4): 572-588.

Sedor, Noelle. 2015. "Why Fee and Dividend is Better than Cap and Trade at Fighting Climate Change." Los Angeles Times, March 5.

Shepsle, Kenneth A. and Barry R. Weingast. 1984. "Political Solutions to Market Problems.” American Political Science Review 78:417-434.

Shepsle, Kenneth A. and Barry R. Weingast. 1994. "Positive Theories of Congressional Institutions." Legislative Studies Quarterly 19(2):149-179.

Speck, Stefan. 2008. "The Design of Carbon and Broad-Based Energy Taxes in European Countries.” Vermont Journal of Environmental Law 10: 31-59.

Stavins, Robert N., ed. 1988. Project 88 - Harnessing Market Forces to Protect Our Environment: Initiatives for the New President. A Public Policy Study sponsored by Senator Timothy E. Wirth and Senator John Heinz. Washington, D.C.

Stavins, Robert N. 1995. "Transaction Costs and Tradeable Permits." Journal of Environmental Economics and Management 29: 133-146.

Stavins, Robert N. 1996. “Correlated Uncertainty and Policy Instrument Choice." Journal of Environmental Economics and Management 30: 218-232.

Stavins, Robert N. 1997. "Policy Instruments for Climate Change: How Can National Governments Address a Global Problem?” The University of Chicago Legal Forum, volume 1997, pp. 293-329. 
Stavins, Robert N. 1998. "What Can We Learn from the Grand Policy Experiment? Positive and Normative Lessons from $\mathrm{SO}_{2}$ Allowance Trading." Journal of Economic Perspectives 12(3): 69-88.

Stavins, Robert N. 2003. "Experience with Market-Based Environmental Policy Instruments." Handbook of Environmental Economics, Volume I, eds. Karl-Göran Mäler and Jeffrey Vincent, Chapter 9, pp. 355-435. Amsterdam: Elsevier Science.

Stavins, Robert N. 2006. “Vintage-Differentiated Environmental Regulation.” Stanford Environmental Law Journal, Volume 25, Number 1 (Winter), pp. 29-63.

Stavins, Robert N. 2007. A U.S. Cap-and-Trade System to Address Global Climate Change. The Hamilton Project, Discussion Paper 2007-13. Washington, D.C.: The Brookings Institution.

Stavins, Robert N. 2008. “A Meaningful U.S. Cap-and-Trade System to Address Climate Change.” Harvard Environmental Law Review 32(2): 293-371.

Stavins, Robert N. 2010. "Both Are Necessary, But Neither is Sufficient: Carbon-Pricing and Technology R\&D Initiatives in a Meaningful National Climate Policy.” An Economic View of the Environment. Blog, October 21.

Stavins, Robert N. 2011. “Polarized Politics Paralyze Policy.” The Environmental Forum 28(6): 16.

Stavins, Robert N. 2012. “Cap-and-Trade, Carbon Taxes, and My Neighbor’s Lovely Lawn.” An Economic View of the Environment. Blog, October 24.

Stavins, Robert N. 2014. “What are the Benefits and Costs of EPA's Proposed CO2 Regulation?” An Economic View of the Environment. Blog, June 19.

Stepp, Matthew, and Alex Trembath. 2013. “A Climate Policy That Would Actually Work.” The Hill. October 11.

Stigler, George J. 1971. “The Theory of Economic Regulation.” Bell Journal of Economics 2:3-21.

Tschirhart, John T. 1984. "Transferable Discharge Permits and the Control of Stationary Source Air Pollution: A Survey and Synthesis." In Economic Perspectives on Acid Deposition Control, Thomas D. Crocker, ed. Boston: Butterworth.

United Nations. 2015. “Paris Agreement.” Adopted December 12; entered into force November 4, 2016.

U.S. Environmental Protection Agency. 1985. Office of Policy Analysis. Costs and Benefits of Reducing Lead in Gasoline, Final Regulatory Impact Analysis. Washington, D.C.

U.S. Environmental Protection Agency. 2014. "Regulatory Impact Analysis for the Proposed Carbon Pollution Guidelines for Existing Power Plants and Emission Standards for Modified and Reconstructed Power Plants.” EPA-452/R-14-002 (June).

U.S. House of Representatives. 2018. “Energy Innovation and Carbon Dividend Act of 2018,” H.R. 7173, $115^{\text {th }}$ Congress, introduced November 27.

U.S. House of Representatives. 2019. "Resolution 109 Recognizing the duty of the Federal Government to create a Green New Deal.” Washington, D.C.: $116^{\text {th }}$ Congress, $1^{\text {st }}$ Session, introduced by Ms. Ocasio-Cortez, February 7. 
Weber, Thomas A., and Karsten Neuhoff. 2010. "Carbon Markets and Technological Innovation." Journal of Environmental Economics and Management 60: 115-132.

Weisbach, David. 2010. "Instrument Choice is Instrument Design." In U.S. Energy Tax Policy, ed., Gilbert E. Metcalf, pp. 113-158. Cambridge, United Kingdom: Cambridge University Press.

Weitzman, Martin L. 1974. “Prices vs. Quantities.” Review of Economic Studies, 41(4): 477-491.

Weitzman, Martin L. 2014. "Can Negotiating a Uniform Carbon Price Help to Internalize the Global Warming Externality?” Journal of the Association of Environmental and Resource Economists 1-2: 29-49.

Weitzman, Martin L. 2017. “On a World Climate Assembly and the Social Cost of Carbon.” Economica 84: 559-586.

World Bank Group. 2016. Emissions Trading in Practice: Handbook on Design and Implementation. Partnership for Market Readiness and International Carbon Action Partnership. Washington, D.C.

World Bank Group. 2018. State and Trends of Carbon Pricing. Washington, D.C.

World Bank Group. 2019. “Carbon Pricing Platform.” Accessed February 12. 